\title{
A REVISION OF THE SUMATRAN PARADOXOSOMATIDAE (DIPLOPODA, POLYDESMIDA) IN THE MUSEO CIVICO DI STORIA NATURALE AT GENOA*)
}

\author{
by \\ C. A. W. JEEKEL \\ Institute of Taxonomic Zoology (Zoölogisch Museum), University of Amsterdam, The Netherlands
}

\begin{abstract}
Redescriptions are given of the Sumatran Paradoxosomatidae described by Silvestri, 1895, and previously referred to the genus Strongylosoma Brandt, 1833. S. inerme Silv. is referred to the genus Dajakina Jeekel, 1963 (Orthomorphini). S. filum Silv. is made the type-species of the new genus Margaritosoma, which includes also S. nanum Silv. and Oxidus sequens Chamberlin, 1945, the latter from Java. For S. vellutatum Silv. the new genus Ecbinopeltis is proposed. Margaritosoma and Echinopeltis are both referable to the Sulciferini. S. infaustum, S. trifasciatum, S. modiglianii and S. simillimum are referred to the genus Sundanina Attems, 1914. S. elongatum Silv, is referred to the genus Sundaninella Jeekel, 1968. For S. dentatum Silv. the new genus Batakina is proposed (Sundaninini). S. birtellum Silv. is referred to the genus Tectoporus Carl, 1902 (Tectoporini).
\end{abstract}

\section{INTRODUCTION}

Most of what has become known of the paradoxosomatid fauna of Sumatra and adjacent smaller islands originates respectively from the Dutch and Italian expeditions of $\mathrm{M}$. Weber and $\mathrm{E}$. Modigliani during the last decennia of the previous century. The material collected by Weber was studied by Pocock (1894), whereas the collections made by Modigliani were the object of a paper by Silvestri (1895).

Owing to the short descriptions and the absence or inadequacy of illustrations, Silvestri's substantial contribution suffered the fate of an almost complete disregard. One may even say that this early paper of the great Italian entomologist greatly obstructed the development of our knowledge of the Sumatran diplopod fauna, although it is only fair to emphasize that Silvestri fully re-

*) Based on data accumulated through the aid of a grant (I 954-36) from the Netherlands Organisation for the Advancement of Pure Research (Z.W.O.) and the Italian National Council of Research (C.N.R.). venged himself in the field of diplopod taxonomy by the publication of many sound contributions in later years.

During a visit to Genoa several years ago the collection of Sumatran diplopods was located in the dark cellars of the Museo civico di Storia Naturale where it was stored in jars awaiting scientific rediscovery, in a condition as if they were left there by the author just the day before, and as a silent witness of curatorial expediency of several generations of Italian museum biologists.

The present paper gives the results of the reexamination of the Sumatran Paradoxosomatidae described by Silvestri and preserved in the Genoa museum. The taxonomic data were tentatively incorporated in an earlier paper (Jeekel, 1968), but the publication of the full details has been delayed owing to unforseen circumstances.

In total Silvestri described or recorded 17 species from Sumatra and the islands off the west coast, and all but two, Strongylosoma nigricorne Pocock, 1894, and Centrodesmus discrepans Silvestri, 1895 , are treated in the subsequent pages. The nomenclatorial changes may be summarized as follows:

Strongylosoma vellutatum Silv. = Ecbinopeltis (nov. gen.) $v$.

Str. birtellum Silv. $=$ Tectoporus b. (Tectoporini) (Sulciferini)

Str. filum Silv. = Margaritosoma (nov. gen.) f. (Sulciferini)

Str. nanum Silv. = Margaritosoma $n$. (Sulciferini)

Str. elongatum Silv. = Sundaninella e. (Sundaninini)

Str. dentatum Silv. = Batakina (nov. gen.) d. (Sundaninini)

Str. infaustum Silv. = Sundanina $i$. (Sundaninini)

Str. niasense Silv. = Sundanina $n$. (Sundaninini)

Str. inerme Silv. = Dajakina $i$. (Orthomorphini)

Str. carneum Poc. = Sundanina c. (Sundaninini)

Str. flavicoxis Poc. = Sundaninella spec. (Sundaninini)

Str. trifasciatum Silv. = Sundanina t. (Sundaninini)

Str. modiglianii Silv. = Sundanina m. (Sundaninini)

Str. simillimum Silv. = Sundanina s. (Sundaninini)

Str. coarctatum (Sauss.) = Orthomorpha c. (Orthomorphini) 
The species will be treated in a systematic sequence.

\section{SYSTEMATIC PART}

\section{Tribe ORTHOMORPHINI Brölemann, 1916}

This tribe is represented in the Sunda area (the Malay Peninsula, Sumatra, Borneo and Java) by the following genera:

Orthomorpha Bollman, 1893 - Malay Peninsula, Java (Farther India, Lombok)

Gigantomorpha Jeekel, 1963 - Borneo (Celebes) Dajakina Jeekel, 1963 - Borneo, Sumatra Nesorthomorpha gen. ined. Jeekel, in press Java

Diglossosternum gen. ined. Jeekel, in press - Java Sphalmatogonus gen. ined. Jeekel, in press Sumatra.

With regard to the interrelationship of these genera the following remarks may be made. It appears that, on account of the structure of the gonopod tibiotarsus, two main groups can be distinguished. One group has the tibiotarsus simple and undivided except for some tiny lappets at the very apex. To this group belong Orthomorpha and probably Sphalmatogonus. In the other group the tibiotarsus has a distinct apical division, or rather, the lamina medialis has near its end a, generally laminate, branch which parallels and extends about as far as the apex proper. This group includes the remaining four genera mentioned above.

Of these four genera it seems that Diglossosternum is most closely related to Gigantomorpha. Nesorthomorpha may come nearest to Antheromorpha Jeekel, 1968, a genus well represented in Farther India. The relationship of Dajakina seems less evident, although this genus probably is related most closely to Antheromorpha as well.

The relationship within this group of genera can be expressed in three vicariant distributional patterns as follows:

1. Orthomorpha (Farther India, Malay Peninsula, Java) - Sphalmatogonus (Sumatra).

2. Antheromorpha (Farther India) - Dajakina (Borneo, Sumatra) - Nesorthomorpha (Java).

\author{
3. Gigantomorpha (Borneo, Celebes) - Diglos- \\ sosternum (Java).
}

Dajakina Jeekel, 1963

Dajakina Jeekel, 1963: 220; Jeekel, 1968: 46.

This genus was proposed for the reception of two closely related species occurring in Borneo. The presently redescribed Dajakina inermis (Silvestri) is perhaps related most closely to these two Bornean species, although in 1968 it was considered to be sufficiently distinct to warrant the eventual proposal of a new generic name. For the time being, however, this species is referred to Dajakina in order not to indulge into a too great fragmentation of the taxonomy of the group. The discovery of annectent forms in the future may lead to a decision whether or not the differences between inermis and its Bornean congeners are of sufficient importance to be formalized by the proposal of a new generic name.

\section{Dajakina inermis (Silvestri, 1895)}

Figs. 1-6.

Strongylosoma inerme Silvestri, 1895: 741.

Materia l. - Sumatra: Si Rambè, 1890-1891, E. Modigliani, ô holotype.

Description. - Colour: pale castaneous, with the venter, sternites and legs paler, yellowish brown.

Width: $2.3 \mathrm{~mm}$.

Head and antennae: labrum of single specimen damaged. Clypeus rather weakly convex, rather weakly impressed towards the labrum. The lateral border widely rounded, with a distinct notch above the labrum. Headplate smooth, rather shiny, setiferous punctation rather dense in the clypeus, becoming moderate in the frontal region. Vertex with a single pair of hairs. Antennal sockets separated by one and a half times the diameter of a socket or by three quarters of the length of the 2nd antennomere. Postantennal groove moderately developed, the swelling in front weakly prominent. Vertex moderately convex, sulcus rather weakly 
impressed, not reaching the upper level of the antennal sockets. Antennae rather long, slightly incrassate, distinctly club-shaped. Relative length of antennomeres: $2 \mathrm{nd}=3 \mathrm{rd}>4 \mathrm{th}=5 \mathrm{th}=6 \mathrm{th}$; the 6 th antennomere $11 / 13$ th of the length of the 2nd. Pubescence moderate in proximal antennomeres, becoming dense in the distal ones.

Collum: of about the same width as the head, subtrapezoidal in dorsal outline (fig. 1). Anterior border faintly convex or almost straight in the middle, widely rounded more laterally and straight towards the sides. Posterior border widely concave in middle part, becoming straight more laterally. Lateral sides rather widely, elliptically rounded. Surface smooth, polished, rather weakly convex in the middle, a little more convex towards the sides. No hairs, although some minute pits are visible. In the middle a fine longitudinal furrow. Marginal rim of lateral sides thin, rather weakly defined.

Body somites: weakly constricted by a narrow waist which is finely longitudinally ribbed down to halfway the sides, and is sharply demarcated from the prosomites. Prosomites dull, with a fine cellular structure. Metatergites more shiny, smooth, hairless. Transverse furrow weakly impressed, present from the 2 nd to about the 16 th somite. In most somites the furrow remains separated from the dorsal delimitation of the paranota by about the dorsoventral diameter of a poriferous paranotum. Sides smooth or a little rugulose, finely subgranular in the 3 rd and 4 th somites. Pleural keels present up to the 10th somite. They are represented in the 2 nd somite by a small triangular lappet, in the 3rd and 4th somites by complete, rounded ridges. In the 5 th and subsequent somites the pleural keels are represented by a swelling on the caudal half of the sides ending in a slightly upcurved ridge. In the 6th somite this ridge ends caudally in a minute triangular lappet projecting slightly caudad of the margin of the somite. Towards the 10th somite the ridges are gradually vanishing.

Paranota: rather weakly developed (figs. 2-5). Second somite scarcely as wide as collum. Its paranota situated on a low level, thin and crestlike. The anterior border weakly convex, the lateroanterior edge with a blunt lateral prominence. Lateral border almost straight or faintly convex.
Posterior edge scarcely prominent, obtusely angular, narrowly rounded, not produced. The $3 \mathrm{rd}$ and 4th somites are of the same width as the 2 nd. Their paranota are represented by a slight swelling, dorsally demarcated by a furrow. From a dorsal aspect the sides are widely rounded, with a scarcely prominent obtuse posterior edge. Paranota of 5th and subsequent somites very widely rounded from a dorsal aspect, the poreless ones hardly convex. Caudal edges prominent, acutely angular and sharply pointed, particularly in the poreless somites. The caudal edges are slightly produced caudad, projecting beyond the margin of the somite from the 9 th onwards. The posterior edges become more and more elongate and spiniform in the somites of the posterior half of the body, the spine pointing a little upward. Pores lateral, in posterior somites lateroventral, in a slight excavation. Dorsal furrow of paranota not reaching the waist, and in posterior somites even quite remote from the waist. Dorsoventral width of poriferous paranota one and a half times that of poreless ones. Ventral demarcation distinct only in the caudal part of the paranota.

Sternites and legs: sternites of middle somites a little broader than long. Transverse furrow of cross impressions almost obsolete in the middle of the sternites, the longitudinal furrow very wide. Pubescence moderately dense. Sternite of 5th somite not modified, without sternal process. Sternite of 6 th somite with the middle deeply concave and not elevated above the ventral level of the metasomal ring. Sternites of 7th and 8th somites without particulars. Legs rather long and rather slender, the prefemora somewhat incrassate. Relative length of podomeres: $3 \mathrm{rd}>6 \mathrm{th}=5 \mathrm{th}>2$ nd $>4$ th; the 6th podomere three fifths of the length of the 3rd. Pubescence moderately dense, in tibiae and tarsi rather dense. Tarsal and tibial brushes present in almost all the legs, but thinning out in the legs of the 17th somite and absent in the last two pairs.

Anal somite: epiproct rather broad and rather long; the sides parallel, the lateral setiferous tubercles prominent. Apex truncate with a pair of widely separated rounded slender cones directed straight backwards. Paraprocts a little rugulose, the setiferous tubercles almost obsolete. Marginal 

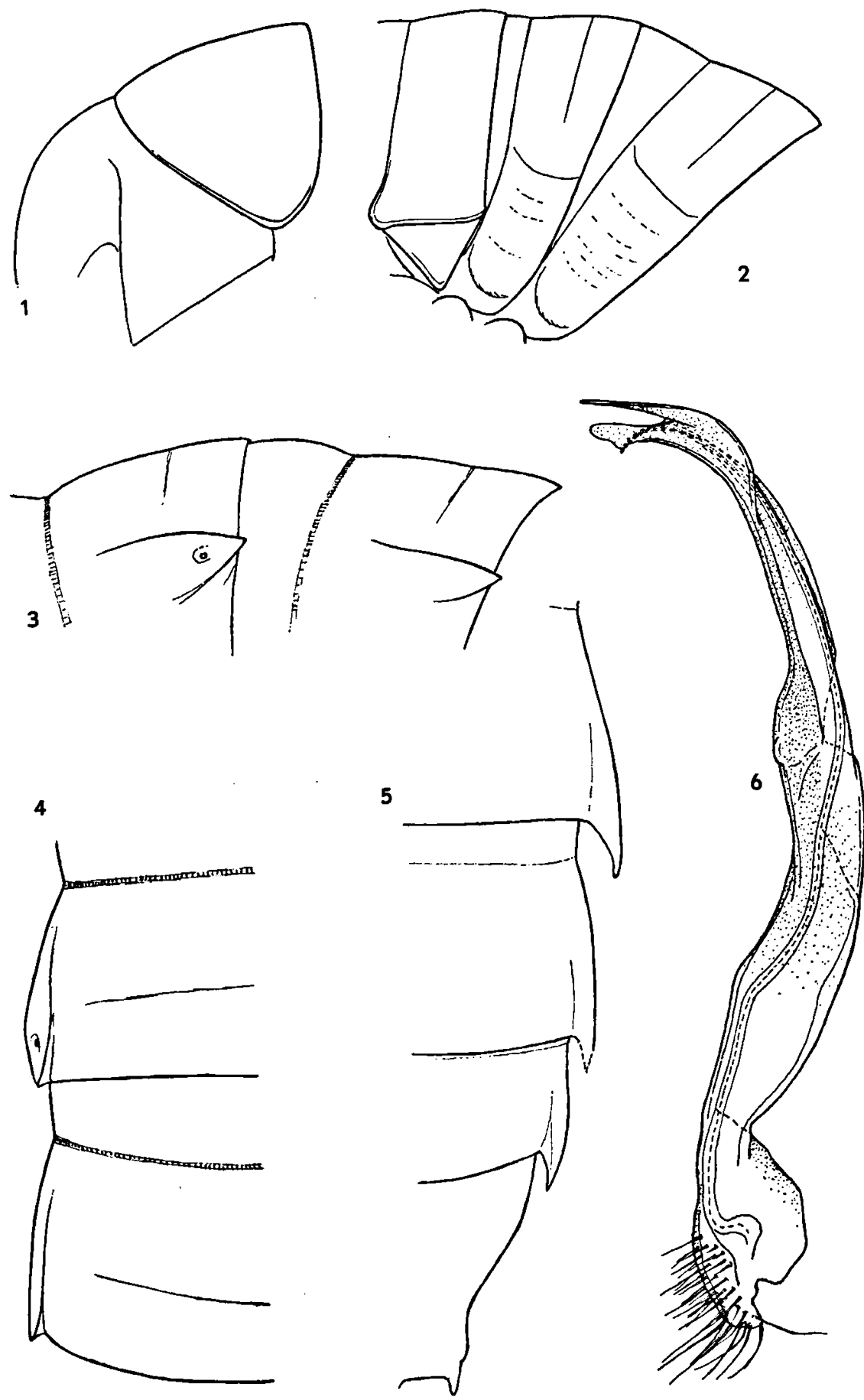

Figs. 1-6. Dajakina inermis (Silvestri, 1895), $\hat{o}$ holotype: 1, left side of collum and adjacent parts of head, lateral aspect; 2, left side of 2 nd to 4th somites, lateral aspect; 3, left side of 10th and 11th somites, lateral aspect; 4, id., dorsal aspect; 5 , right side of 17 th to 20 th somites, dorsal aspect; 6 , telopodite of right gonopod from a medial and slightly anterior aspect. 
rims rather low and of moderate width. Hypoproct missing in only specimen available.

Gonopods (fig. 6): coxa missing in specimen studied. Prefemur relatively short, ovoid, its longitudinal axis somewhat deviating from the axis of the femorite. Femorite long and slender, weakly curving caudad. Postfemoral division distinctly demarcated on lateral side. Spermal channel following a somewhat undulate course along the medial side of the femorite. Solenomerite arising from the anterior side of the distal end of the femorite, gradually tapering. Tibiotarsus long and slender, only weakly curved caudad, consisting of a lamina lateralis, which is the main support of the solenomerite, and near the end a lamina medialis which before the apex of the tibiotarsus bears a separate lamella reaching slightly distad of apex.

\section{Orthomorpha Bollman, 1893}

\section{Orthomorpha coarctata (De Saussure, 1860)}

Polydesmus coarctatus De Saussure, 1860: 297.

Strongylosoma coarctatum; Silvestri, 1895: 744.

M a teri a 1. - Sumatra, Benkoelen, E. Modigliani, 1 t , 1 \%; Siboga [= Sibolga], April 1886, E. Modigliani, 2 ô $\hat{o}$, $1 \%$, and fragments of 4 specimens; Lumut, E. Modigliani, 2 of $\hat{s}$; Padang, E. Modigliani, 1 o, 2 $\%$ \%

Nias, Gunung Sitoli, 1886, E. Modigliani, 1 \&

R e m a rks . - Silvestri's identification of this common tropical ubiquitous species has been confirmed. Considering the fact that Orthomorpha occurs both in Java and in the Malay Peninsula it is quite interesting that it is represented in Sumatra only by this probably introduced species.

\section{Tribe SULCIFERINI Attems, 1898}

This tribe, which is well represented in most countries of the Asian mainland, is almost completely lacking in the Sunda area. Up to now, Anoplodesmus dyscheres Attems, 1898, reported from Deli, Sumatra, but possibly an introduced form there, was known as the only representative of the tribe in Sumatra. Two new genera, Margaritosoma and Echinopeltis, are added to the Sumatran list but both are hardly typical members of the Sulciferini.
In its external characters Margaritosoma seems quite unrelated to any of the other sulciferine genera and rather approaches certain genera of the Sundaninini. Nevertheless, the gonopods of Margaritosoma show most of the typical characters of the Sulciferini.

Echinopeltis, externally characterized by weakly developed paranota and a furlike pubescence of the metasomites, seems to come up nearest to the Indian genus Chondromorpha, with which it appears to share most of the basic gonopod characters. It seems to have a great external similarity with the somewhat enigmatic genus Eudasypeltis Pocock, 1895, known from southern Burma, which, however, appears to have Orthomorpha-like gonopods and was tentatively referred to the tribe Orthomorphini on that account (Jeekel, 1968: 57).

Margaritosoma nov. gen.

Generic diagnosis. - Small-sized Sulciferini with 20 somites and a normal pore formula. Head without particulars, antennae rather long.

Somites strongly constricted; the stricture broad, with strong longitudinal ribs. Metatergites smooth, with transverse series of long setae. Transverse furrow absent or faintly indicated. Pleural keels absent from the 5th somite onwards.

Paranota very weakly developed in a few anterior segments, vestigial or completely absent from the 5th somite onwards.

Sternites of middle somites longer than wide, with well-developed cross impressions. Sternite of 5 th somite of male with a long process between the anterior coxae. Legs long, in the male with tarsal and tibial scopulae disappearing in the second half of the body. No other sexual modifications.

Gonopods with relatively short coxa. Prefemur ovoid. Femorite narrow at base, widening strongly distad, no postfemoral section demarcated. Course of spermal channel sigmoidal along the medial side of the femur. Solenomerite arising from the anterior side of the apex of the femorite, gradually tapering. Tibiotarsus rather complicated, arising from the caudal side of the apex of the femorite. Lamina lateralis rather weakly developed, lamina 
medialis well developed, bearing near the end an additional lobe pointing distad. Laterad of lamina lateralis a large shieldlike lamina extends about as far as the apex of the solenophorous part of the tibiotarsus.

Ty pe-s pecies. - Strongylosoma filum Silvestri, 1895 .

R e m a r ks. - This genus of slim and graceful small paradoxosomatids contains, besides the two species from Sumatra and Enggano treated below, also the Javanese species Oxidus sequens Chamberlin, 1945. Moreover, I have seen material of a fourth species occurring near Padang, Sumatra. Undoubtedly, many undiscovered forms occur throughout Sumatra, Java and the neighbouring smaller islands.

As was noted already, the classification of this genus is a rather difficult problem. In the structure of the gonopods it approaches the Sulciferini, and at least for the time being its reference to this tribe seems the most logical solution. Nevertheless, some doubt exists because the external morphology, in particular the structure of the somites with the broad waist, the relatively strong constriction and the weak development of the paranota, strongly suggests that of certain genera belonging to the Sundaninini.

It is possible that the rather complicated type of gonopods as found in Margaritosoma represents a primitive structure from which the more simple type of gonopods as in Opisthodolichopus Verhoeff, 1941, and Batakina nov. gen. is derived. If this were true, it is clear that the concept of the tribe Sundaninini should be thoroughly revised.

\section{Margaritosoma filum (Silvestri, 1895)}

Fig. 7.

Strongylosoma filum Silvestri, 1895: 739, fig. 5.

Materia 1. - Sumatra: Si Rambè, E. Modigliani, ô lectotype, $\hat{\delta}$ paratype, $2 \& \&$ paratypes, and fragments of 2 ô $\hat{o}$ paratypes.

Description. - Colour: pale reddish castaneous. Venter, sternites and legs paler reddish yellowish brown or legs pale yellowish.
Width: $\delta: 0.75-0.80 \mathrm{~mm}$ (lectotype $0.80 \mathrm{~mm}$ ); o: $1.25 \mathrm{~mm}$.

Head and antennae: labrum moderately emarginate, tridentate. Clypeus moderately convex, moderately impressed towards the labrum. Lateral border widely rounded, with a distinct notch near the labrum. Headplate smooth, polished, densely to moderately setiferous up to above the antennal sockets, vertex with one single pair of hairs. Antennal sockets separated by slightly more than the diameter of a socket, or by half the length of the 2nd antennomere. Postantennal groove moderately impressed. Vertex moderately convex, the sulcus rather weakly impressed, running downward to just above the upper level of the antennal sockets. Antennae rather long, distinctly clavate, moderately to densely pubescent. Relative length of antennomeres: 2 nd $=3 \mathrm{rd}=4$ th $>5$ th $=6$ th; the 6 th antennomere equal to three quarters of the length of the 2 nd.

Collum: distinctly narrower than the head, subsemicircular to reniform in dorsal outline. Anterior border weakly rounded in the middle, becoming only slightly more convex towards the lateral sides and laterally even slightly emarginate. Posterior border widely emarginate in the middle, widely rounded laterally. Lateral border regularly and rather widely rounded. Surface smooth, shiny, with few hairs, weakly convex in the middle, more so towards the sides. Marginal rim thin, the premarginal furrow gradually fading away towards the middle of the anterior border.

Body somites: strongly constricted in the waist area. The prosomites somewhat dull by the presence of a very fine cellular structure. Waist broad, strongly longitudinally ribbed down to the level of the stigmata. Metatergites smooth, shiny, without transverse furrow. No hairs on the 2 nd metatergite, a few on the $3 \mathrm{rd}$. Subsequent metatergites with two irregular rows of 8 to 10 and 12 long hairs, which are in part rubbed off. Sides smooth, not granulate in anterior somites. Pleural keels of 2nd and 3 rd somites represented by distinct ridges; in the 2nd somite a small caudal lappet, in the 3rd not produced caudally. Pleural keels faintly indicated in the 4th somite, absent from the 5th onwards.

Paranota: almost completely absent. The 2nd 
somite narrower than the collum, the 3rd narrower than the $2 \mathrm{nd}$, and the 4 th subequal to the $3 \mathrm{rd}$. Paranota of 2nd somite situated on a low level, represented by very weakly prominent, narrow ridges. Anterior border weakly convex with the lateral edge obtuse, rounded. Lateral border faintly convex, bearing three long setae. Posterior edge moderately widely rounded. Paranota of $3 \mathrm{rd}$ and 4th somites weakly prominent and only dorsally demarcated by a furrow. Paranota of 5th and subsequent somites absent; only in the poriferous somites the area around the pores is slightly swollen. No demarcating furrows except a vague one on the 6th somite.

Sternites and legs: sternites of middle somites about one and a half times longer than wide, rather densely pubescent. Cross impression rather deep, especially the transverse furrow. No sternal cones. Sternite of 5 th somite with an elongate tongue-shaped process, with slightly converging sides and a rounded apex, which projects slightly in front of the sternite. At the anterior surface of the apex a fine brush of minute setae. Transverse furrow and caudal half of sternite normal. Sternite of 6th somite only weakly modified, the longitudinal furrow of the cross impression somewhat broader than normal. Sternite of 7 th somite with laterocephalad of gonopod opening, at the level of the coxa of the ambulatory leg, a rounded conical process projecting cephalad of caudal margin of waist. Sternite of 8 th somite almost normal and only slightly more concave anteriorly. Legs long and rather slender, the prefemora scarcely incrassate. Pubescence moderately dense, in tarsi dense. Brushes of tibiae and tarsi dense, from the legs of the 7th somite onwards gradually thinning out, absent in the last two pairs of legs. Setae rather long. Relative length of podomeres: 3rd $>6$ th $>$ 5th $=2$ nd $>4$ th; the 6 th podomere three quarters of the length of the $3 \mathrm{rd}$.

Anal somite: epiproct rather long, of moderate width. Its sides moderately converging with a pair of distinct lateral setiferous tubercles beyond which the epiproct narrows to a narrowly truncate and slightly emarginate apex. Paraprocts with rather thick and rather high marginal rims. Setae not on tubercles. Hypoproct trapezoidal, the sides and posterior border faintly concave. Setae not on distinct tubercles.
Gonopods (fig. 7): coxa of moderate length, rather stout, the distal section distinctly bent caudad. Prefemur ovoid, its longitudinal axis almost in line with the axis of the femorite. Coxa with an anterior and lateral setiferous area, setae of this area and of the prefemur longish. Femorite straight, strongly widening distad, of moderate length, without postfemoral division. Spermal channel having a sigmoid course along the medial side of the femorite. Solenomerite of moderate length, arising from the anterior side of the distal end of the femorite. Tibiotarsus rather complicated, consisting of three lamellae. Lamina medialis elongate and rather narrow, apically subdivided into two hyaline membranes. Lamina lateralis split into two lamellae, a minor lamella opposing the base of the lamina medialis, and a much larger, lateral blade. Like the solenomerite, the body of the tibiotarsus is curving caudad.

Female: distinctly more robust than the male, with the somites relatively less constricted. Anten-

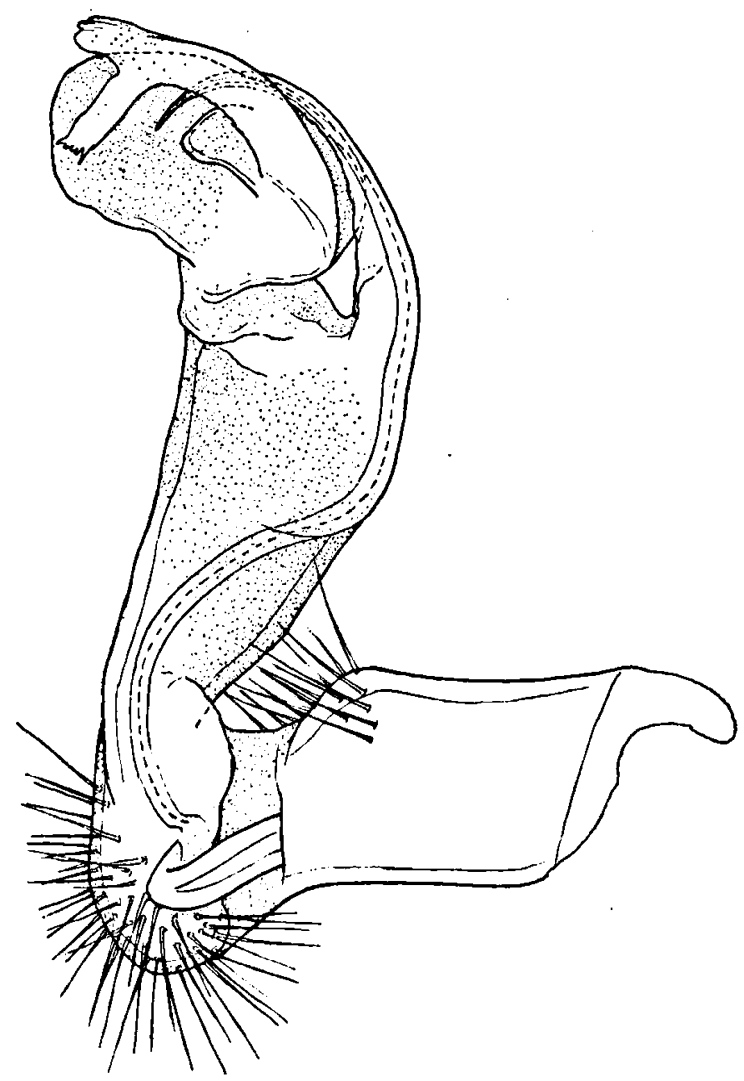

Fig. 7. Margaritosoma filum (Silvestri, 1895), ô paratype, right gonopod, medial aspect. 
nae separated by slightly more than half the length of the 2nd antennomere. Longitudinal ribs of waist conspicuously less developed, the waist narrower than in the male. Metatergites of 5 th to 17 th somites with a weak transverse furrow. Pleural keels of 2 nd, 3 rd and 4 th somites ending caudally in distinct rounded lappets, which in the 3 rd somite project caudad of margin of somite, in the 4th just attain that margin. Pleural keels absent from the 5 th somite onwards. Sternites of middle somites slightly longer than broad, the cross impressions less deep than in the male. Pubescence of sternites as in the male, becoming, however, sparser in the caudal somites. Legs relatively a little shorter than in the male and a little more slender.

\section{Margaritosoma nanum (Silvestri, 1895)}

Fig. 8.

\section{Strongylosoma nanum Silvestri, 1895: 739.}

Materia 1. - Engano: Bua-Bua, May 1891, E. Modigliani, $\hat{\delta}$ lectotype, $\hat{\delta}$ paratype.

Des cription. - Colour: similar to that of Margaritosoma filum, and like that species with the three distal podomeres darker than the proximal ones.

Width: $\delta$ : $0.9 \mathrm{~mm}$.

Head and antennae: as in $M$. filum. Antennal sockets separated by one and one third times the diameter of a socket, or by about half the length of the 2nd antennomere. Vertex with three pairs of hairs. Relative length of antennomeres: 2 nd $=$ 3rd $>4$ th $>5$ th $>6$ th; the 6th antennomere six sevenths of the length of the 2 nd.

Collum: as in $M$. filum, but the lateral part of the anterior margin not emarginate but straight. Some hairs in the middle and some along the anterior margin.

Body somites: as in $M$. filum but the waist decidedly less coarsely ribbed. Metatergites without transverse furrow or this furrow faintly indicated. Setae of metatergites apparently mostly rubbed off. In middle somites there seems to be a transverse series of 16 long setae along the posterior margin from just below the pore level upwards.
Another row of about 6 hairs just behind the waist. Anterior somites with less hairs.

Paranota: as in $M$. filum, but the 3 rd somite a little wider than the 4 th.

Sternites and legs: pubescence of sternites moderate to sparse. Sternal process of 5th somite subrectangular, somewhat longer than broad, the apex straight truncate with rounded lateral edges, the sides slightly constricted at the base, otherwise as in $M$. filum. Caudal part of sternite of 5th somite with a deep transverse furrow, otherwise normal. Sternite of 6th somite with a weakly impressed transverse furrow; the longitudinal furrow very wide and the middle of the sternite caudally not raised above the ventral level of the metasomal ring. Sternite of 7 th somite without lateroanterior protuberances. Sternite of 8 th somite normal. Legs as in $M$. filum, but the tibial and tarsal brushes thinning out already in the pregonopodial legs and disappearing gradually in the second half of the body.

Anal somite: epiproct shorter than in M. filum, with sides more strongly converging. Setiferous tubercles distinct, but apex of epiproct not as elongate as in $M$. filum. Paraprocts and hypoproct as in $M$. filum, but the caudal margin of the latter slightly convex.

Gonopods (fig. 8): very similar to those of M. filum, but on the whole more elongate and somewhat less strongly curved caudad. Femorite at anterior side with a papillate area, the spermal channel following a more undulate course. In the tibiotarsus the medial lamella of the lamina lateralis is relatively larger, the lamina medialis is broader, and its apex more deeply split. Solenomerite more distinctly sheathed by lamina medialis and lamina lateralis. The lateral blade is relatively more narrow than in $M$. filum.

\section{Echinopeltis nov. gen.}

Generic diagnosis. - Medium-sized Sulciferini with 20 somites and a normal pore formula. Headplate densely setiferous; antennae of moderate length.

Somites moderately constricted; the waist or stricture rather narrow, beaded in dorsal half. 


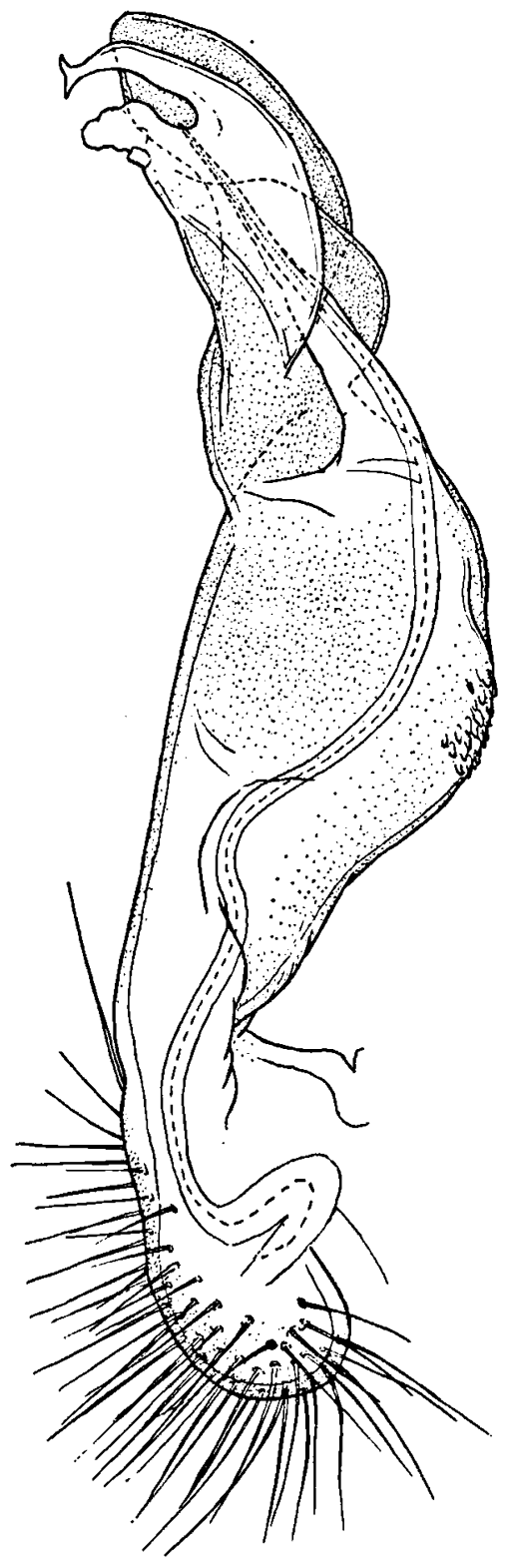

Fig. 8. Margaritosoma nanum (Silvestri, 1895), ô lectotype, telopodite of right gonopod, medial aspect.

Metatergites with large granules and densely covered with small setiferous granules, giving the animal a furry look. Transverse furrow well developed. Pleural keels absent.

Paranota weakly to very weakly developed.

Sternites of middle somite a little longer than wide, with well-developed cross impressions. Sternite of sth somite of male with a moderately developed process between the anterior coxae. Legs of moderate length, rather stout; the last pairs distinctly incrassate. No tibial or tarsal scopulae or other sexual modifications in the legs of the male.

Gonopods with a relatively strongly developed femorite, without distinct demarcation between the femoral and postfemoral sections. Tibiotarsus suggesting Chondromorpha Silvestri, 1897, but the apex of the tibiotarsus rather deeply split into two parallel laminae.

Ty pe-s pecies. - Strongylosoma vellutatum Silvestri, 1895.

R e m a r ks . - This monobasic genus seems to be related most closely to the less typical Sulciferini like Chondromorpha Silvestri from India and Ceylon. It is easily distinguished from that genus by the dense pubescence of head and metasomites and by the much longer gonopod femorite.

Externally Echinopeltis suggests Eudasypeltis Pocock, 1895, which apparently has a similar dense pubescence of the head and metasomites, but which belongs to the Orthomorphini.

\section{Echinopeltis vellutatus (Silvestri, 1895) Figs. 9-15.}

Strongylosoma vellutatum Silvestri, 1895: 738.

M a teria l . - Sumatra: Si Rambè, 1890-1891, E. Modigliani, $\hat{o}$ lectotype, $2 \hat{o} \hat{o}$ paratypes, 2 $\$$ paratypes, and various fragments.

Des cription. - Colour: pale castaneous all over, with the labral area, ventral side of the somites including the sternites and legs, and the ventral side of the anal somite paler yellowish brown.

Width: $\delta:$ : $2.0-2.3 \mathrm{~mm}$ (lectotype $2.0 \mathrm{~mm}$ ); १: $2.5-2.8 \mathrm{~mm}$.

Head and antennae: labrum rather widely and moderately deeply emarginate, tridentate. Clypeus moderately convex, moderately impressed towards the labrum. Lateral border rather widely rounded with a distinct and rather deep notch near the labrum. Headplate densely setiferous, subgranulate, weakly shining. Antennal sockets separated by five sevenths of the diameter of a socket or by two thirds of the length of the 2 nd antennomere. 
Postantennal groove well impressed, the wall in front rather weakly prominent. Vertex moderately convex, not demarcated from frons. Sulcus of vertex weakly impressed, running downward to just below the upper level of the antennal sockets. Antennae of moderate length, somewhat incrassate, distinctly clavate. Relative length of antennomeres: 2nd $=3$ rd $>4$ th $>5$ th $<6$ th; the 6th antennomere nine tenths of the length of the 2 nd. Pubescence dense in proximal antennomeres, becoming very dense in the distal ones.

Collum: about as wide as the head, subreniform to subelliptical in dorsal outline (fig. 9). Anterior border widely convex, becoming gradually more strongly rounded towards the lateral sides. Posterior border widely concave in the middle, becoming widely convex towards the lateral sides. Lateral border rather widely and symmetrically rounded. Surface rather weakly transversely convex in the middle, more strongly convex towards the sides, densely setiferous. Setae arising from numerous minute granules and from larger granules which are partly dispersed over the surface, partly arranged in a transverse row along the caudal margin. Marginal rim of lateral border fine, rather weakly defined by a furrow which disappears towards the middle of the anterior border.

Body somites: moderately constricted. The waist rather narrow, beaded down to half way the sides. Prosomites very dull, with a silky structure. Metatergites densely granular and setiferous as the collum. Tegument dull. The larger granules at the posterior border distinct, becoming conical near the paranota. Transverse furrow present from the $3 \mathrm{rd}$ to the 17 th somite, weakly indicated on the 2 nd and 18th. Furrow well impressed, without sculpture, running laterad to quite near the base of the paranota. Sides granular and setiferous as the tergites, but lacking larger granules. Pleural keels absent, but on all somites from the 4th to the 17th or 18 th, the lower part of the sides is somewhat inflated.

Paranota: weakly to very weakly developed (figs. 10-12). The 2 nd somite a little wider than the collum. Its paranota weakly developed, with two lateral teeth, its anterior and lateral margins slightly convex. The paranota are thin crests, situated a little below the level of those of the 3rd somite. Anterior edge obtuse, posterior edge about rectangular, subacuminate, slightly produced caudad. The 3rd and 4th somites scarcely wider than the 2nd. Paranota weakly developed, anterolaterally rather widely rounded, more faintly rounded laterally and with two lateral teeth. In addition a weak lateroanterior tooth. Posterior edge acute, slightly produced but not projecting caudad of margin of the somite. Paranota of subsequent somites represented by elongate swellings which end caudally in a projecting conical process. Paranota without dorsal demarcation and ventrally demarcated only near the posterior edge in poriferous somites. Pores not in a distinct excavation and somewhat concealed from above. Poreless paranota narrower dorsoventrally than poriferous ones. Only in the 18th somite the caudal edge projects very slightly beyond the margin of the somite.

Sternites and legs: sternites of middle somites a little longer than wide; cross impressions with both the longitudinal and the transverse furrows well impressed. Sternites densely granular and setiferous. Process between anterior legs of 5th somite a little longer than broad, the apex laminate, rounded with a median incision. Near the apex anteriorly a dense brush of short setae. The process is directed somewhat cephalad and projects distinctly in front of the sternite. Sternite otherwise normal, only caudally slightly excavated. Sternite of 6th somite with an almost V-shaped excavation, the middle hardly elevated above the ventral level of the metasomal ring. Sternite of 8th somite almost normal, only anteriorly a little more deeply concave. Legs of middle somites of moderate length, rather stout. Relative length of podomeres: 3 rd $>6$ th $>5$ th $=2$ nd $>4$ th (fig. 13). Posterior legs (fig. 14) more incrassate, those of last pair thickest. Pubescence dense, no brushes, although the tarsi in the first pair of legs are very densely setiferous.

Anal somite: entirely densely granular and setiferous, including paraprocts and hypoproct. Epiproct rather broad and very thick, sides moderately straight converging, the end simply truncate, without the usual lateral setiferous tubercles or terminal cones. Paraprocts with narrow and low marginal rims. Hypoproct rather broadly triangular, the sides widely convex, the end obtusely angular. 

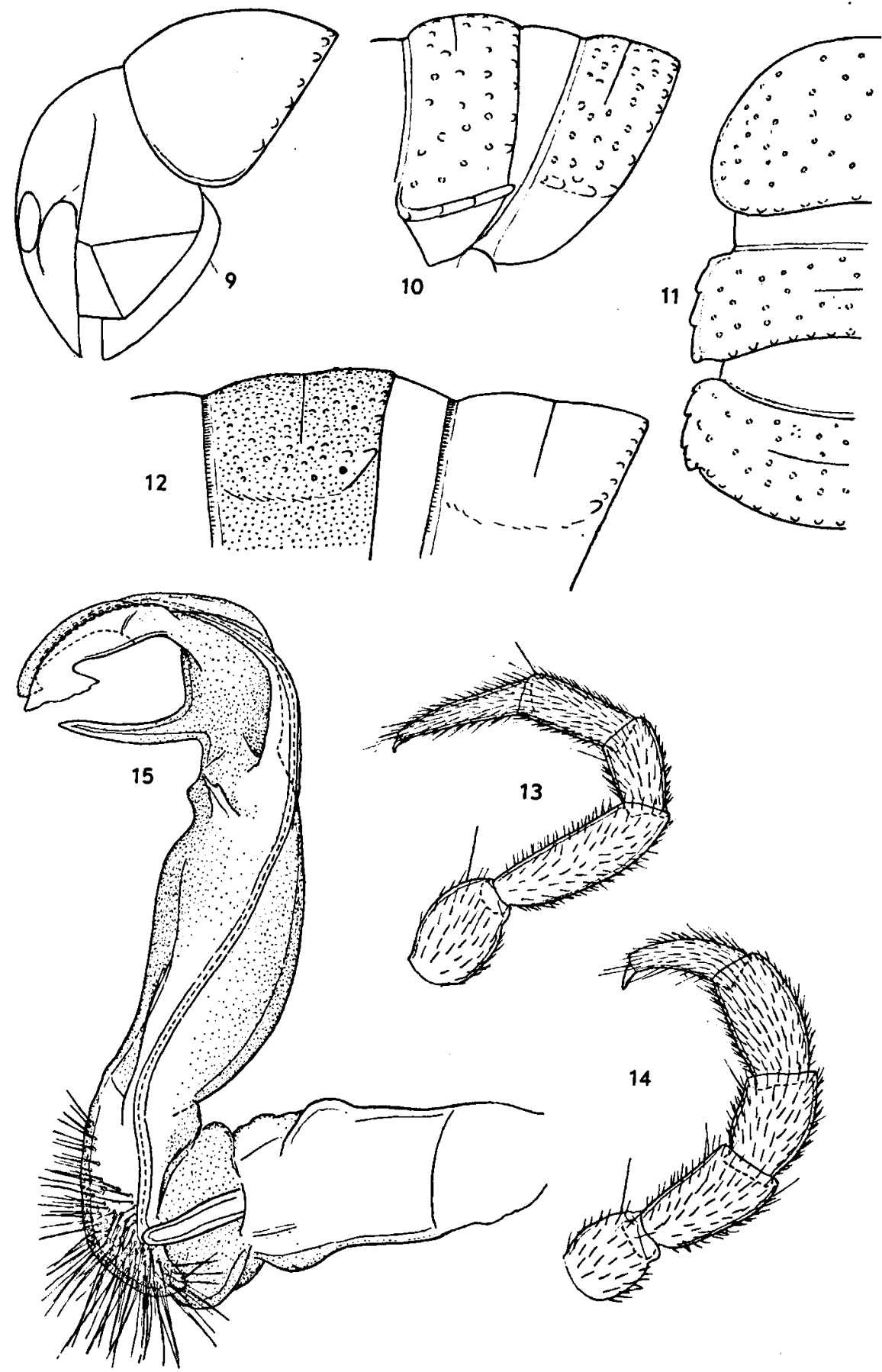

Figs. 9-15. Echinopeltis vellutatus (Silvestri, 1895), $\hat{o}$ lectotype: 9, left side of collum and head, lateral aspect (setiferous granulation omitted); 10, left side of 2 nd and 3rd somites, lateral aspect (id.); 11, collum, 2nd and 3 rd somites, left side, dorsal aspect (id.); 12, left side of 10 th and 11 th somites, lateral aspect (setiferous granulation indicated on 10th somite, pubescence omitted); 13, ambulatory leg of 7th somite; 14, leg of ultimate pair; 15, right gonopod, medial aspect. 
Gonopods (fig. 15): coxa straight, somewhat clavate distally. Prefemur ovoid, its longitudinal axis weakly deviating from the axis of the femorite. Femur relatively long, rather stout, widening towards the middle and narrowing near the distal end. No clear demarcation between the femoral and postfemoral sections. Tibiotarsus semicircular, relatively rather short, consisting of a solenophorous part and a basal spur pointing caudad. Solenophore with a well-developed lamina lateralis and a much smaller lamina medialis. Near its base the lamina medialis bears an elongate separate lappet which parallels the apex of the solenophore proper. Spermal channel running almost straight along the medial side of the femorite towards the base of the solenomerite, which arises from the medioanterior side of the apex of the femorite. Solenomerite gradually tapering, only its distal half sheathed by the solenophore.

Female: antennae similar to those of the male; the sockets separated by the same distance as in the male. Sternites as long as wide. Legs much more slender than in the male, but the last two pairs similarly incrassate. Sides of epiproct a little more strongly converging than in the male.

\section{Tribe SUNDANININI Jeekel, 1968}

As was pointed out already in connection with the classificatory status of Margaritosoma, the concept of the Sundaninini is still not yet satisfactorily settled. In 1968 the following genera were referred to the tribe:

Arthrogonopus Jeekel, 1963 - Borneo

Borneonina Jeekel, 1963 - Borneo

Kalimantanina Jeekel, 1963 - Borneo

Opisthodolichopus Verhoeff, 1941 - Sumatra, Java

Sundanina Attems, 1914 - Sumatra, Sabang, Simalur, Nias, Mentawei, Java

Sundaninella Jeekel, 1968 — Sumatra, Nias, Indochina.

To this list is added here the new genus Batakina, based on Strongylosoma dentatum Silvestri, Sumatra.

As was emphasized in 1968, Artbrogonopus on the one hand, and Borneonina and Kalimantanina on the other, are rather remotely related to each other as well as to the other genera. Artbrogonopus stands apart by having a very sharp demarcation between the femoral and postfemoral sections of the gonopod femorite, and Borneonina and Kalimantanina are distinguished particularly by the relatively well-developed lamina medialis of the tibiotarsus of the gonopods. The relationship of these Bornean genera, not only to the other genera of the tribe, but also to each other is certainly not established beyond doubt.

On the other hand, the remaining genera Batakina, Opisthodolichopus, Sundanina and Sundaninella form a cohesive group, even to such an extent that their characterization is still somewhat arbitrary.

The latter group contains the dominant element of the Sumatran paradoxosomatid fauna, and most of the conspicuous species of the family found on the island belong to it. In spite of this, it is interesting to note that the group extends its range into Indochina towards the north and into Java to the east with some isolated species. The fact that the Sundaninini are not represented in Borneo by members of this group, but by two clearly more isolated groups of genera, stresses once again the separate zoogeographical position of that island within the Sunda area.

\section{Sundanina Attems, 1914}

Sundanina Attems, 1914: 198; Jeekel, 1957: 155; Jeekel, 1968: 48.

This is perhaps the most well-defined genus of the Sundaninini. It has 12 species most of which have been described from Sumatra, from Pulu Weh down to Padang, whereas one species each has been reported from the islands off the west coast, Simalur, Nias and Sipora, and one was said to have been collected in Java ( $S$. bataviae (Humbert \& De Saussure, 1869)). The latter species has been recorded by Carl (1922) from Deli, Sumatra, and the original description may have been based on wrongly labelled material.

Silvestri described five species, four of which are redescribed in the present paper. A redescription of the fifth, S. niasensis (Silvestri), based on 
identified material, was published by me in 1957 and is confirmed by the examination of the type material.

It is interesting to note that three of the species described by Silvestri were labelled as coming from Si Rambè and are apparently sympatric, a rather unusual condition in the family.

Key to the species of Sundanina, based on gonopod characters.

1. Femorite with a single, rather long, acuminate process, and sometimes the vestige of a second process . . 2

- Femorite with two distinct, rodlike, short triangular or lamellar processes

2. Femoral process hooklike, its distal half directed cephalodistad . . . . . S. simillima (Silvestri, 1895)

- Femoral process simply slightly curved or slightly sigmoidal, pointing caudodistad .

3. Femoral process arising from quite near the base of the solenomerite . . . S. gastrotricha (Attems, 1898)

- Femoral process arising remote from the base of the solenomerite .

4. Distal lamina of tibiotarsus rounded. The apical lobe, guiding the tip of the solenomerite, finely fringed . S. aphanes (Attems, 1898)

- Distal lamina of tibiotarsus acuminate. The apical lobe, guiding the tip of the solenomerite, irregularly shaped but not fringed . . . S. infausta (Silvestri, 1895)

5. Both femoral processes of an irregular, lamellate shape, not acuminate . . . S. simalurensis Jeekel, 1957

- Both femoral processes either shortly triangular or elongate rodlike, acuminate

6. Both femoral processes small, triangular, pointing caudad . . . . . . . S. trifasciata (Silvestri, 1895)

- Both femoral processes elongate . . . . . 7

7. The two femoral processes pointing towards almost opposite directions: the medioproximal process pointing proximad and caudad, the laterodistal process curving mediad and pointing distad

S. niasensis (Silvestri, 1895)

- The two femoral processes pointing towards the same direction: caudad or more or less distad . . . 8

8. The proximal femoral process more than three times as long as the distal one. Solenomerite simply curved . . S. carnea (Pocock, 1894)

- The proximal femoral process at most about two times longer than the distal one. Solenomerite either simply curved or somewhat sigmoid .

9. The proximal femoral process about two times longer than the distal one. . . . . . . . 10

- Both femoral processes of similar length, or at least not differing as much in size. . . . . . . 11

10. Solenomerite simply curved . S. xantbonota Attems, 1930

- Solenomerite sigmoid . S. modiglianii (Silvestri, 1895)

11. Preapical process of tibiotarsus well developed, the margin serrulate

S. bataviae (Humbert \& De Saussure, 1869)

- Tibiotarsus without large preapical process, the apex triangularly acuminate . . S. solitaria (Carl, 1909)
Sundanina infausta (Silvestri, 1895)

Figs. 16-17.

Strongylosoma infaustum Silvestri, 1895: 740.

Material. - Sumatra: Si Rambè, 1890-1891, E. Modigliani, ô lectotype, 2 \% paratypes.

Description. - Colour: head and antennae light brown, the end of the 6th and 7th antennomeres darkened, the tip whitish. Collum darker, reddish brown, darkest along the margins. Somites and legs also reddish brown, the venter, sternites and the two basal podomeres slightly more yellowish. Anal somite of same colour as preceding somites, darker above, paler below.

Width: $\delta: 2.2 \mathrm{~mm}$; $q: 3.0 \mathrm{~mm}$.

Head and antennae: labrum weakly and widely emarginate, tridentate. Clypeus moderately convex, rather strongly impressed towards the labrum. The lateral border widely rounded, with a rather deep notch near the labrum. Headplate smooth, shiny, rather densely setiferous up to just above the antennal sockets, vertex with a single pair of hairs. Antennal sockets separated by scarcely more than the diameter of a socket, or by about half the length of the 2nd antennomere. Postantennal groove moderately impressed, the wall in front moderately prominent. Vertex moderately convex, the sulcus rather weakly impressed, running downward to upper level of antennal sockets. Antennae long, distinctly clavate; pubescence moderate to dense. Relative length of antennomeres: 2nd < $3 \mathrm{rd}>4$ th $=5$ th $>6$ th; the 6 th antennomere six sevenths of length of 2 nd.

Collum: slightly narrower than the head, subsemicircular in dorsal outline. Anterior margin almost evenly rounded, a little more strongly so at the lateral sides. Posterior border weakly emarginate in the middle, faintly convex more laterally, and straight near lateral sides, with a very weak notch near the lateral rounding. Lateral border rather widely rounded; the marginal rim narrow, almost completely fading away at middle of anterior border. Surface smooth, shiny, rather weakly convex in the middle, somewhat more convex towards the sides. Some short setae along the anterior border and in the middle of the surface.

Body somites: moderately constricted. Pro- 
somites somewhat dull by the presence of a fine cellular structure. Waist of moderate width, dorsally narrowed; distinctly ribbed or beaded down to just below the level of the paranota, finely striate down to the level of the stigmata. Metatergites smooth and shiny, hairless. Transverse furrow present from the 5 th to the 17 th somite, disappearing laterally at a distance of two times the diameter of a paranotum dorsad of its upper delimitation. Sides smooth or a little rugulose, granulose up to the 4th somite. Pleural keels present up to the 9th somite; in the 2nd somite caudally produced into a slightly projecting acutely angular lappet. Pleural keels of 3 rd somite represented by well-developed ridges, dorsally demarcated by a furrow and ending caudally in an acutely pointed projecting lappet. In the 4 th somite the anterior part of the keel is indistinct and the caudal lappet less developed. In the 5th somite there is only a ridge near the caudal margin of the somite, caudally rounded and not projecting. In the 6 th somite the caudal ending of the keel is slightly produced. Keels of 7 th somite similar to those of 5th. In the 8th and 9th somites the keels are only faintly indicated. On the whole the pleural keels are slightly less developed than in S. niasensis.

Paranota: similar to those of $S$. niasensis, but the caudal edges of the paranota of the 3rd and 4th somites obtusely rounded. The 2 nd somite wider than the collum, the 3 rd narrower than the 2nd, the 4 th wider than the $3 \mathrm{rd}$.

Sternites and legs: sternites of middle somites almost one and a half times longer than broad. Cross impressions distinct, the transverse furrow a little more deeply impressed than the longitudinal one. Pubescence moderate to rather sparse. Sternite of 5 th somite with a subrectangular process between the anterior legs. The process is somewhat longer than wide, the sides are very slightly convexly converging, the end truncate with the lateral edges rounded and the apex faintly excised. Anterior surface covered with short straight hairs, but without a dense brush. Transverse furrow and caudal part of sternite scarcely modified, only the caudal side a little more widely excavated. Sternite of 6th somite without transverse furrow, the middle widely excavated but not level with the ventral side of the metasomal ring. Sternite of 7 th somite with a granulose ridge laterad of gonopod aperture. Sternite of 8 th somite not modified. Legs long and rather slender, the last pair elongate. Relative length of podomeres: $3 \mathrm{rd}>6$ th $>$ 5 th $>4$ th $>$ 2nd; the 6th podomere four fifths of the length of the 3rd. The 2nd podomere incrassate in the legs of the anterior half of the body. Pubescence moderate, rather dense in the tarsi; hairs long and distributed on all sides, not especially on basal podomeres. Tarsal and distal tibial brushes thick in the 1st and 2nd pair, thinning out in the $3 \mathrm{rd}$, 4th and 5th pairs and absent from the 6th pair onwards.

Anal somite: epiproct as in S. niasensis. Paraprocts rugulose, otherwise as in $S$. niasensis. Hypoproct a little narrower apically than in $S$. niasensis.

Gonopods (figs. 16-17): coxa relatively short and slender. Prefemur somewhat elongate, laterally demarcated from the femorite. Femorite rather slender, elongate, rather strongly curved near the base. No postfemoral region indicated. The femorite has only a single process, the more lateral is vestigial. Tibiotarsus relatively short, not demarcated from femorite. Solenomerite also relatively short, applied to medial side of tibiotarsus, and ending near the preapical lappet of the tibiotarsus. Apex of tibiotarsus elongate triangular.

Female: antennal sockets separated by one and one seventh of the diameter of a socket or by four sevenths of the 2nd antennomere. Antennae relatively a little shorter and stouter than in the male. Somites relatively less constricted, with the waist a little narrower, especially dorsally. Pleural keels of 2nd and 3rd somites projecting distinctly, of 4 th only slightly behind the margin. In the 5th and 7 th somites they are rounded, in the 6th slightly pointed, but not projecting, in the 8th and subsequent somites they are obsolete. Width of sternites six sevenths of their length. Second podomere of same length as 4th.

R e m a r k s . - Among the species of Sundanina with a single femoral process this one comes obviously nearest to $S$. aphanes (Attems, 1898), described from Deli north of Lake Toba, from which it may be distinguished by the characters mentioned in the key. $S$. aphanes appears to be a 
little larger (width 3.0 to $3.3 \mathrm{~mm}$ ), but otherwise quite similar in its external morphology. $S$. gastrotricha (Attems, 1898) is also closely related, but
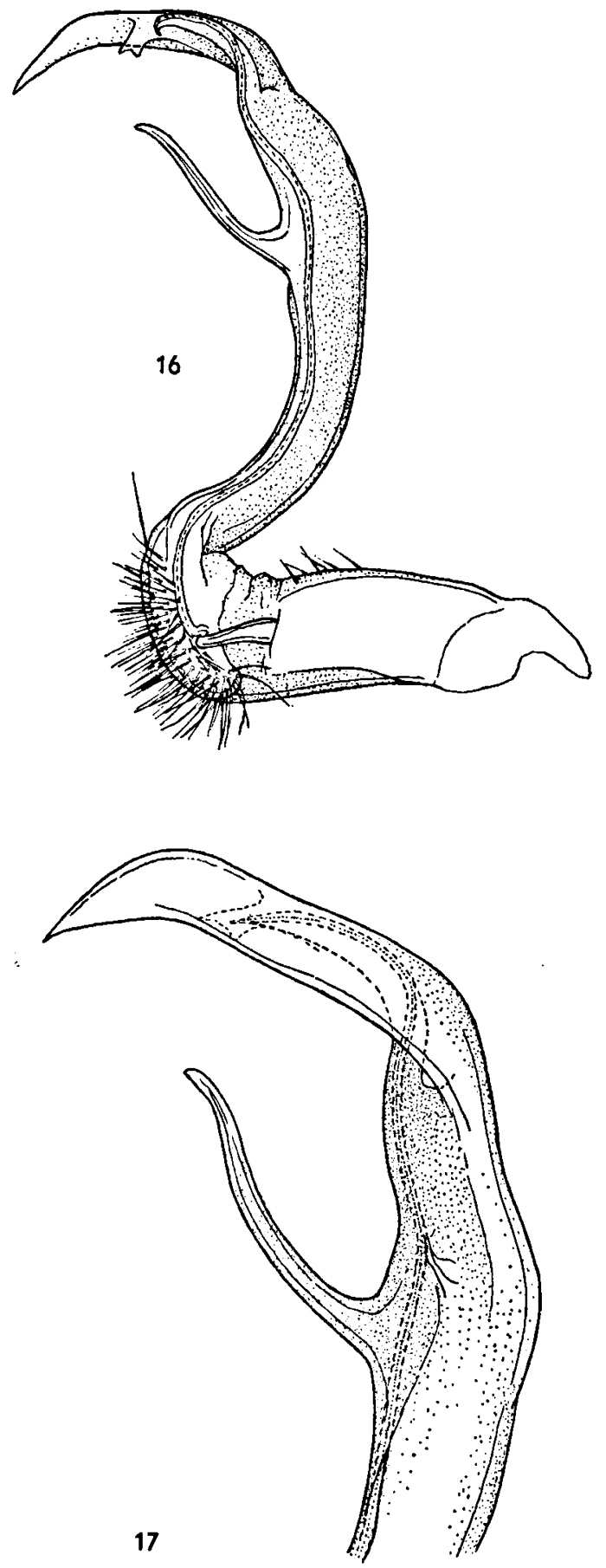

Figs. 16-17. Sundanina infausta (Silvestri, 1895), ô lectotype: 16 , right gonopod, medial aspect; 17 , apical half of telopodite of left gonopod, lateral aspect. its femoral process is much stouter at the base and arises near the base of the solenomerite. It seems to be a somewhat larger species (width $3.0 \mathrm{~mm}$ ) and differs apparently in colouration by having two paramedian yellowish spots on the anterior half of each metatergite. S. gastrotricha allegedly lacks pleural keels, but this should be verified. It was described from Lake Toba, so that the relationship of $S$. infausta, $S$. aphanes and $S$. gastrotricha is supported by coherence of their geographical occurrence.

On the other hand, the relationship of $S$. infausta and S. simillima (Silvestri, 1895) seems much more remote, which is hardly amazing considering the occurrence of the latter on the island of Sipora.

\section{Sundanina modiglianii (Silvestri, 1895)}

Figs. 18-21.

Strongylosoma Modiglianii Silvestri, 1895: 742, fig. 6.

Materia 1. - Sumatra: Si Rambè, 1890-1891, E. Modigliani, $\hat{o}$ lectotype, 18 ô $\hat{o}$ paratypes, $13 \% q$ paratypes, and fragments of $10 \hat{\delta} \hat{\delta}$ and $15 \% \&$ paratypes.

De scription. - Colour: head gray brown, darkest in vertex. Antennae blackish brown, except the basal antennomere which is gray brown, tip whitish. Collum gray brown, darkest along the anterior margin. Body somites also gray brown, darkest in the areas of the waist and the transverse furrow of the metatergites, and palest behind the transverse furrow and on the paranota. Venter, sternites and legs also pale gray brown. Anal somite of same colour as body somites.

Width: ô $2.7-3.3 \mathrm{~mm}$ (lectotype $2.9 \mathrm{~mm}$ ); o: $3.3-3.9 \mathrm{~mm}$ (note: the single male specimen measuring $3.3 \mathrm{~mm}$ was lacking the telopodite of both gonopods).

Head and antennae: clypeus rather weakly impressed towards the labrum. Its lateral border widely rounded, a distinct notch near the labrum. Antennal sockets separated by the diameter of a socket or by four ninths of the length of the 2nd antennomere. Postantennal groove well impressed, the wall in front rather weakly prominent. Antennae only slightly clavate, rather stout. Relative length of antennomeres: $3 \mathrm{rd}>2 \mathrm{nd}=4$ th $=$ 
5 th $>6$ th; the 6th antennomere only slightly shorter than the 2nd.

Collum (fig. 18): as wide as the head, subelliptical in dorsal outline. Anterior border widely and almost evenly rounded, laterally straight. Posterior border widely emarginate, slightly convex more laterally, a very slight notch at the lateral side. Lateral border rather widely and regularly rounded. Surface rather weakly convex in the middle, more so towards the sides, smooth with some dispersed hairs. Marginal rim as in $S$. infausta.

Body somites: constriction as in S. niasensis, with a rather narrow stricture, which is distinctly ribbed above, and striate from the middle of the sides down to the level of the sternite. Prosomites as in the other species of the genus. Metatergites shiny, hairless except for some dispersed hairs on the 2nd and 3rd somites. Transverse furrow as in $S$. infausta, a weak furrow also on the 18th somite. Sides smooth, but up to the 4 th somite very slightly granulose. Pleural keels of same general structure as in the other species of the genus, up to the 5th somite with acute triangular caudal lappets projecting behind the margin of the somites. In the 6th and 7th somites the lappets do not project caudad of the margin. In the 8th somite only a small caudal edge, which is weakening in the subsequent somites and obliterated from the 14 th somite onwards.
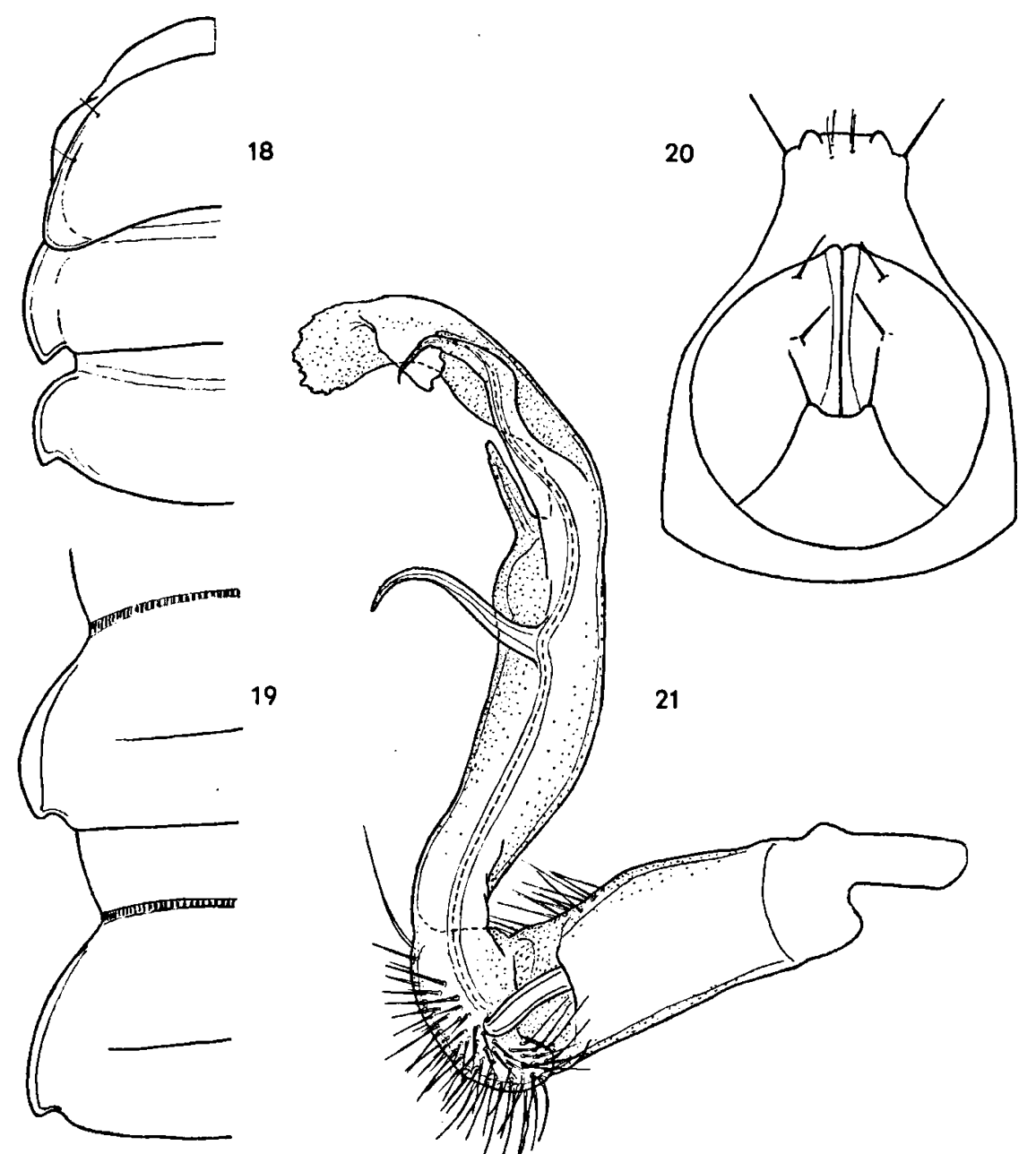

21

Figs. 18-21. Sundanina modiglianii (Silvestri, 1895), ô paratype: 18, left side of head, collum, 2nd and 3rd somites, dorsal aspect; 19, left side of 10 th and 11 th somites, dorsal aspect; 20 , anal somite, ventral aspect; 21 , right gonopod, medial aspect. 
Paranota (figs. 18-19): relative width of anterior somites as in $S$. infausta. Lateral border of paranotum of 2nd somite more strongly rounded than in $S$. niasensis. The posterior edge of the paranota of the 3rd somite acutely angular, projecting caudad of margin of somite. Posterior edge of paranota of 4th somite also acutely angular, projecting caudad of margin. Posterior edges of 5th and subsequent somites with angular edges which are slightly produced posteriorly but are projecting caudad of margin only in the 18th and 19 th somites.

Sternites and legs: sternites as in S. infausta, the cross impressions moderately developed, with the transverse furrow almost disappearing in the middle. Sternite of 5 th somite with a thick process which is about twice as long as broad at the base. In the middle the process is distinctly constricted; its end is truncate and straight. Anterior side of apex with a brush of short hairs. Caudal half of sternite somewhat excavated. Sternite of 6 th somite particularly in the posterior half deeply excavate and scarcely raised above the ventral level of the metasomal ring. Sternite of 7 th somite with a distinct swelling laterocephalad of gonopod aperture. Sternite of 8th somite without particulars. Legs as in S. infausta, but pubescence of ventral side of coxa and prefemur dense except in the legs of the three last leg-bearing somites. Femora and postfemora ventrally rather densely setiferous. Tibial and tarsal brushes thick in a few anterior legs, thinning out gradually in subsequent legs, obsolete in the legs of the 18th somite. Prefemur somewhat incrassate. Relative length of podomeres: 3 rd $>6$ th $>5$ th $>4$ th $=2$ nd; the 6th podomere about three quarters of the length of the 3rd. Last legs not modified.

Anal somite (fig. 20): epiproct ventrally a little concave, thick. Paraprocts leathery, the marginal rims narrow but rather high. Setae on small tubercles.

Gonopods (fig. 21): femorite rather slender, with two well-developed spiniform processes: a proximal one projecting caudad, and a more distal one, about half the length of the proximal, pointing in more distal direction. Tibiotarsus with the preapical lobe serrulate. Solenomerite slightly sigmoid.
Female: antennal sockets separated by almost half the length of the 2 nd antennomere or by the diameter of a socket. Pleural keels of 2 nd to 4 th somites as in the male. In the 6th somite they are less developed than in the 5th, where the caudal edge is rounded and not projecting. Keels of 7 th somite similar to those of the 6th. In the 8th somite they are very slightly produced as in the male, in the 9th to 15 th somites gradually diminishing and weakly indicated near the posterior margin. Length of sternites one and one quarter times their width. Legs with ventral pubescence rather dense in the anterior pairs, only moderate more caudad. The 4 th podomere a little shorter than the 2 nd.

R e m a r k s. - In the structure of the gonopods this species comes up nearest to $S$. xantbonota Attems, 1930, from Pulu Weh, in which, however, the solenomerite is simply curved and not sigmoid. Moreover, $S$. xanthonota is readily distinguished by the presence of a continuous flavous middorsal band, by its smaller size (width of male 2.4-2.6 $\mathrm{mm}$, of female $3.0-3.2 \mathrm{~mm}$ ), somewhat less developed pleural keels, tibial and tarsal scopulae, and numerous minor details (cf. Jeekel, 1957: 154).

\section{Sundanina simillima (Silvestri, 1895)}

Figs. 22-24.

Strongylosoma simillimum Silvestri, 1895: 743, fig. 7.

Materia 1. - Mentavei Isl.: Sipora, Sereinu, May-June 1894, E. Modigliani, ô lectotype, 2 ô $\hat{o}$ paratypes, 8 우 $\$$ paratypes, 1 juv. $\delta$ paratype with 19 somites.

Description. - Colour: head dark coffee brown. Basal antennomere of same colour, the remaining part of the antennae piceous, with only the tip whitish. Collum and body somites dark gray brown, the paranota slightly paler. Venter and sternites pale brownish gray. Legs pale grayish, with the distal end of each podomere faintly darkened; tip of the tarsi piceous, except for the hyaline apex.

Width: ô: $3.1-3.2 \mathrm{~mm}$ (lectotype $3.1 \mathrm{~mm}$ ); o: $3.7-3.8 \mathrm{~mm}$; juv. $\delta: 2.1 \mathrm{~mm}$. 
Head and antennae: labrum moderately deeply and rather widely emarginate, tridentate. Clypeus with the lateral border faintly convex, and a rather weak notch near the labrum. Headplate otherwise similar to $S$. infausta, but the antennal sockets separated by the diameter of a socket or by slightly more than half the length of the 2nd antennomere. Wall in front of the postantennal groove weakly prominent. Sulcus of vertex well impressed, not reaching the upper level of the antennal sockets. Antennae long, stout, moderately clavate. Relative length of antennomeres: 2 nd $=5$ th $>$ 3 rd $=4$ th $>6$ th; the 6th antennomere equal to eleven twelfths of the length of the $2 \mathrm{nd}$.

Collum (fig. 22): a little wider than the head, subsemicircular to subelliptical in dorsal outline. Anterior border widely rounded, slightly more rounded more laterally and straight or even faintly concave towards the lateral sides. Posterior border with a very faint notch near the lateral sides. Lateral sides almost evenly and rather widely rounded. Surface with some dispersed hairs.

Body somites: constriction as in $S$. niasensis, dorsally narrow and longitudinally ribbed, striate down the sides. Metatergites as in the other species of the genus, hairless, except in a few anterior somites. Transverse furrow present from the 5 th to the 17 th or 18 th somites. Sides a little granular in the 2nd and 3rd somites, and in the ventral part of the 4 th. Pleural keels of the 2nd to 4 th somites as in S. modiglianii (with pointed projecting caudal edges), of 5 th somite not pointed, rectangular, and not produced. In 6th and 7th somites a little pointed edge, not projecting.

Paranota (figs. 22-23): similar to those of $S$. niasensis. The 2 nd somite a little wider than the collum, the paranota a little more pointed than in S. niasensis. The 3 rd somite a little narrower than the 2nd, paranota with a caudally produced rectangular posterior edge which projects slightly beyond the margin of the somite. The 4th somite scarcely wider than the 3rd; paranota obtusely angular, not projecting. Posterior edges of paranota of 5 th and subsequent somites obtusely angular, in the 17 th somite rectangular, and in the 18th and 19th somites somewhat acute and slightly projecting.

Sternites and legs: sternites of middle somites almost twice as long as broad, otherwise as in $S$. infausta. Sternal process of 5 th somite about one and a half times longer than wide, not constricted at the base, its apex rounded and weakly bilobate. Anterior side of apex with curved short hairs, but without brush. Posterior part of sternite of 5th somite almost unmodified, the transverse furrow deep. Sternite of 6 th somite deeply excavate, the transverse furrow almost obsolete, the posterior part not raised above the ventral level of the metasomal ring. Sternite of 7 th somite with a welldeveloped knob laterocephalad of gonopod aperture. Sternite of 8 th somite not modified. Legs as in S. infausta; prefemur scarcely incrassate even in the anterior legs. Tibial and tarsal brushes very thin in the first leg, becoming gradually thinner and obsolete from the 8th somite onwards. In particular the two ultimate pairs with distal end of femur, postfemur and tibia a little incrassate, but these legs are not shorter than the preceding ones.

Anal somite: epiproct broad as in S. trifasciata, but the terminal tubercles a little more prominent. Paraprocts smooth, the setae on small tubercles. Hypoproct narrow trapezoidal, the setiferous tubercles scarcely or only slightly projecting, resembling the hypoproct of $S$. modiglianii but the posterior margin straight.

Gonopods (fig. 24): in general aspect very similar to those of $S$. niasensis, but with only a single femoral process instead of two.

Female: antennal sockets separated by slightly more than half the length of the 2nd antennomere. Pleural keels of 2 nd to 4 th somites with caudally projecting triangular edges; in the 5th somite there is a small rectangular lappet not produced caudally, in the 6th somite caudally rounded, in the 7 th somite absent. Sternites one and a quarter times longer than broad. Ventral pubescence of legs as in the male, moderate. The 2 nd and 4 th podomere are of equal length. Hypoproct trapezoidal, the tubercles projecting slightly beyond the straight posterior margin.

Juvenile male: collum more rounded, and paranota less developed than in the adults. Pleural keels as in the adults. Sternites about one and a quarter times longer than broad. Epiproct narrower, like in adults of $S$. modiglianii. 


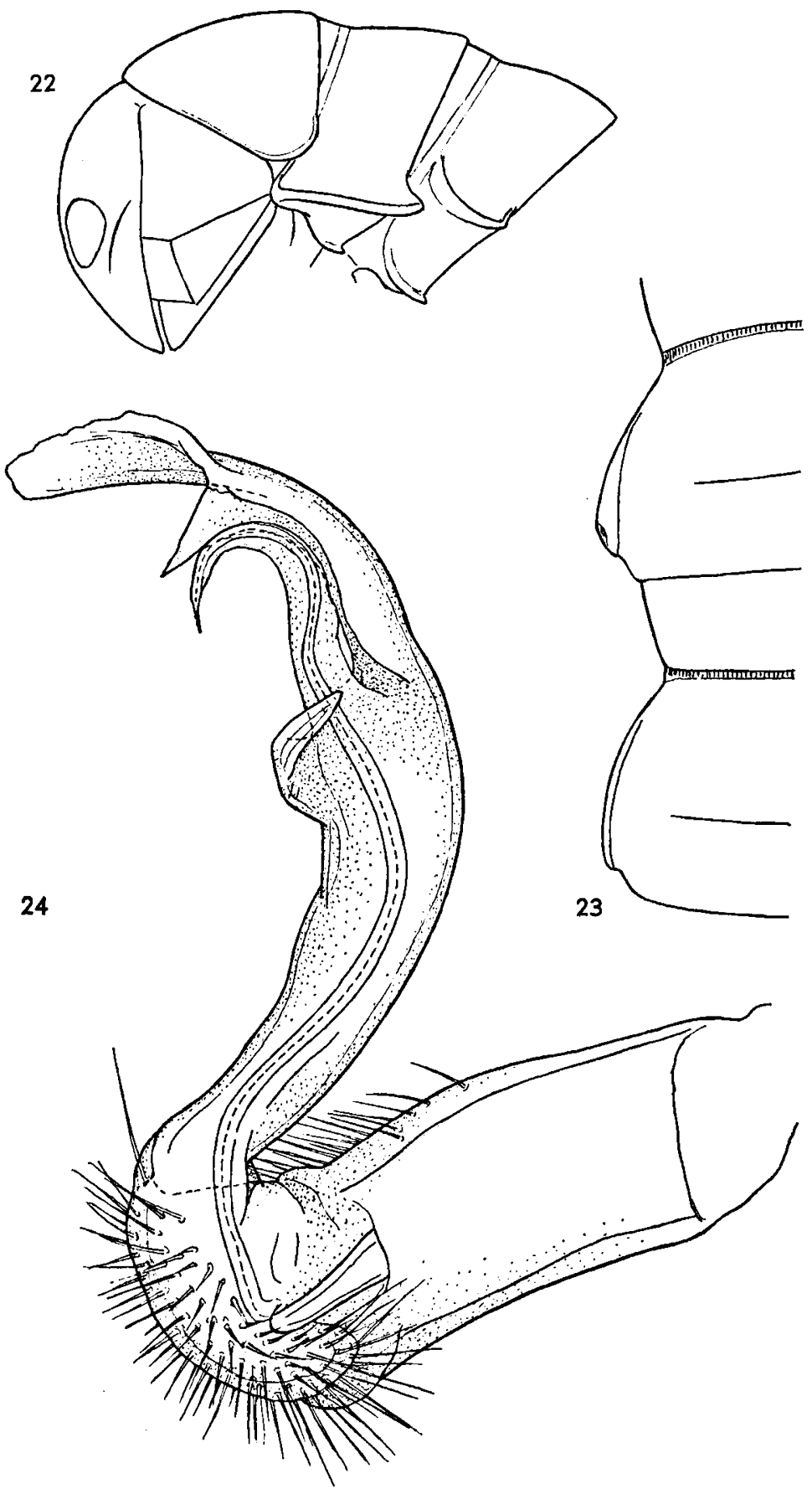

Figs. 22-24. Sundanina simillima (Silvestri, 1895), of lectotype: 22, left side of head, collum and 2nd and 3rd somites, lateral aspect; 23 , left side of 10 th and 11 th somites, dorsal aspect; 24 , right gonopod, medial aspect. 
Remarks. - In spite of the fact that this species has only one femoral process, and therefore belongs to the probably artificial group of species lacking one of these processes, it is apparently closely related to $S$. niasensis. The single process is curved just like the more distal process in $S$. niasensis: mediad and then cephalad and distad. Thus, apparently $S$. simillima has lost the proximal process. $S$. niasensis is also distinct in having yellowish spots on the dorsum, and in several details of its morphology (cf. Jeekel, 1957: 147).

Sundanina trifasciata (Silvestri, 1895)

Figs. 25-31.

Strongylosoma trifasciatum Silvestri, 1895: 742.

Mate ri a I . - Sumatra: Si Rambè, 1890-1891, E. Modigliani, 1 s lectotype, 2 fragments of a juv. $\delta$ paratype.

D e s c ription. - Colour: the available material is apparently rather strongly discoloured. Head yellowish brown, with the antennae of the same colour except for the 6th and 7th antennomeres which are a little darkened. Ground colour of collum and body somites yellowish brown, with traces of three dark castaneous longitudinal stripes, a median stripe broadest about halfway each metatergite, and a lateral stripe on each side just above the paranota and broadest above the posterior part of each paranotum. Probably these stripes are shortly interrupted in the waist area and at the caudal border of each somite. On collum and prosomites the stripes are very faint. The paramedian pale bands separating the dark stripes are each about as broad as twice the width of a dark stripe. Ventral part of somites, anal somite, sternites and legs pale yellowish.

Width: $\delta$ : $3.0 \mathrm{~mm}$, juv. $\delta$ : $2.5 \mathrm{~mm}$.

Head and antennae: labrum rather deeply and narrowly emarginate, tridentate. Clypeus weakly convex, and its lateral margin with only a weak notch near the labrum, otherwise as in S. infausta. Pubescence rather dense to moderate. Antennal sockets separated by one and one sixth times the diameter of a socket or by slightly less than half the length of the 2nd antennomere. In front of the sockets is a shallow impression. Wall in front of the postantennal groove weakly inflated. Sulcus of vertex moderately impressed; vertex with a single pair of setae. Antennae long and not particularly slender, scarcely clavate with only the 6 th antennomere a little wider than the proximal ones. Relative length of antennomeres: 2nd $=3 \mathrm{rd}=$ 4 th $=5$ th $>6$ th; the 6 th antennomere three quarters of the length of the 5th. Pubescence of antennomeres rather dense to dense.

Collum (fig. 25): about as wide as the head, semielliptical in dorsal outline. Anterior border faintly convex in the middle, a little more rounded more laterally, and straight towards the sides. Posterior border scarcely emarginate in the middle, faintly convex more laterally, and straight or faintly emarginate towards the sides. Lateral sides rather widely and symmetrically rounded. Surface somewhat coriaceous, hairless, rather weakly convex in the middle, more so towards the sides. Marginal rim faintly demarcated and thin, anteriorly fading away before reaching the middle of the anterior border.

Body somites: as in S. infausta, but the metatergites coriaceous and with some coarse transverse wrinkles between the waist and the transverse furrow. Sides also somewhat coriaceous, rugulose. Pleural keels similar to those of $S$. infausta, but in the 6 th somite there is a minute rectangular posterior edge, and in the 7th somite the edge is rounded. From the 8 th somite onwards pleural keels are obsolete.

Paranota (figs. 25-26): 2nd somite a little wider than the collum. The paranota with lateral border weakly rounded, the posterior border and lateroposterior edge narrowly rounded, without a distinct angle. Marginal rim dorsally finely demarcated. The 3rd and 4th somites of equal width, and almost as wide as the $2 \mathrm{nd}$. Paranota of 3 rd somite a little declined laterad, very slightly below the level of those of the 4 th. Lateral border widely rounded, slightly more strongly rounded anteriorly; the lateroposterior edge narrowly rounded and slightly projecting. Paranota of 4th somite similar to those of the 3rd but horizontal and not produced caudally. Paranota of 5th and subsequent somites with the caudal edges rounded except in the 18th and 19th somites where they are sub- 
rectangular, pointed. In the 19th somite they project very slightly caudad of the posterior margin of the somite. Poreless paranota with a distinct rim which is narrow in dorsal aspect.

Sternites and legs: sternites as in S. infausta, but sternal process of 5th somite long and stout, almost twice as long as broad at the base, its sides a little diverging, the end truncate and faintly emarginate, the lateral edges rounded. Caudal part of sternite of 5th somite medially deeply incised, the middle not raised above the ventral level of the metasomal ring. The ridge of the sternite of the 7th somite weakly developed and not sharply demarcated. Legs (figs. 28-29) as in
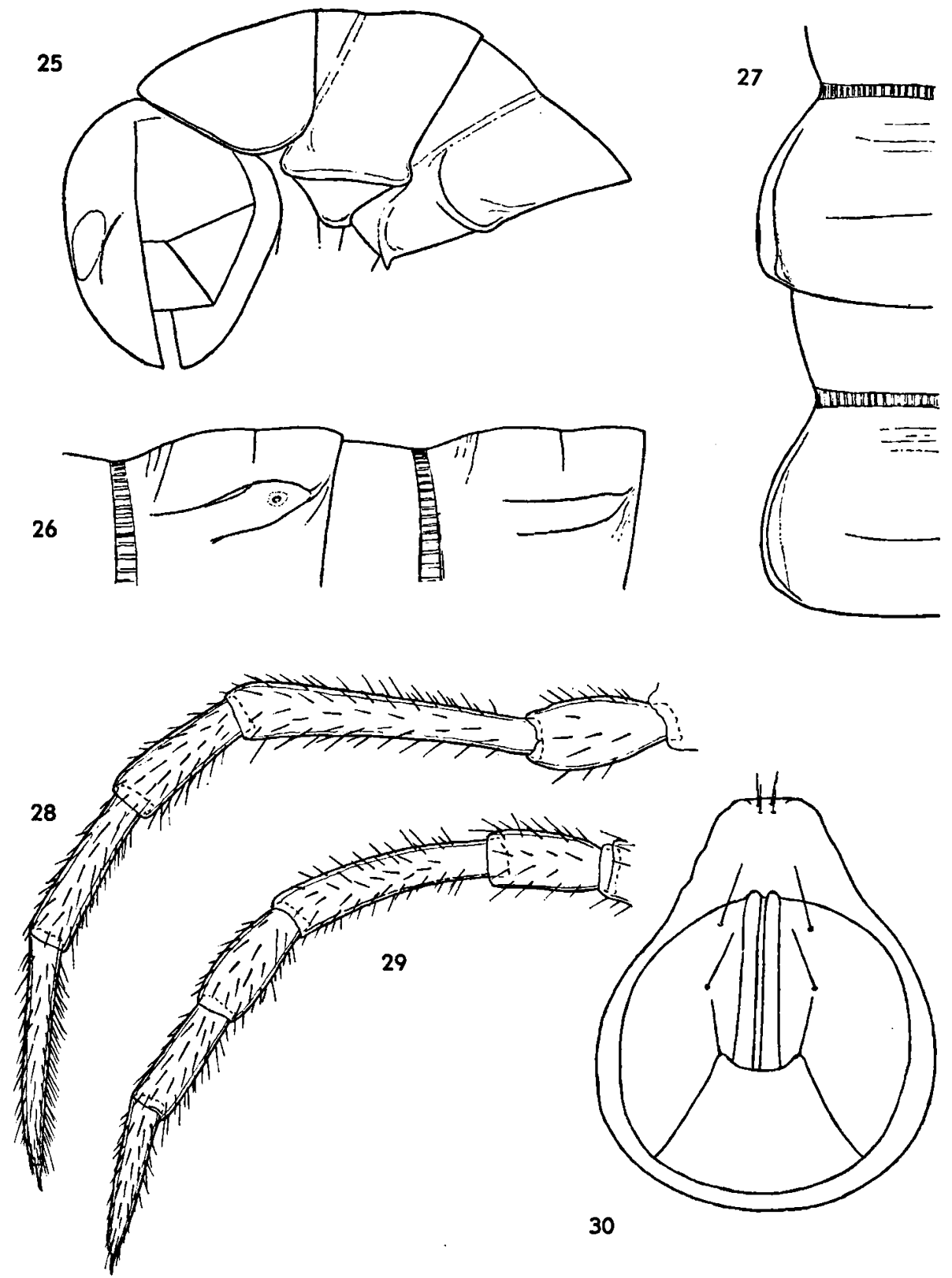

Figs. 25-30. Sundanina trifasciata (Silvestri, 1895), ô lectotype: 25, left side of head, collum and 2nd and 3rd somites, lateral aspect; 26, left side of 10th and 11th somites, lateral aspect; 27, id., dorsal aspect; 28, leg of 10th somite; 29, last leg; 30, anal somite, ventral aspect. 
S. infausta, but the last two pairs a little shorter than the preceding ones, and especially the tarsi short and a little incrassate. Pubescence of legs rather dense, especially in the anterior half of the body. Tibial and tarsal brushes thinning out gradually towards the legs of the 12th somite and practically obsolete from there onwards. The 4 th and 2 nd podomeres are of equal length, the 6th equal to half the length of the 3 rd.

Anal somite (fig. 30): epiproct rather thick, with the ventral side a little concave. Paraprocts not rugulose, the marginal rims narrow and moderately high. Setae on minute tubercles.

Gonopods (fig. 31): femorite straight, near the end a small medioposterior and a lateroposterior process pointing caudad. Tibiotarsus rather abruptly curved caudad, typically voluminous, but otherwise of the usual structure. Solenomerite stout, loosely applied to the tibiotarsus.

Juvenile: the juvenile male specimens have the same colour pattern as the adults, but differ markedly in having all paranota caudally angular

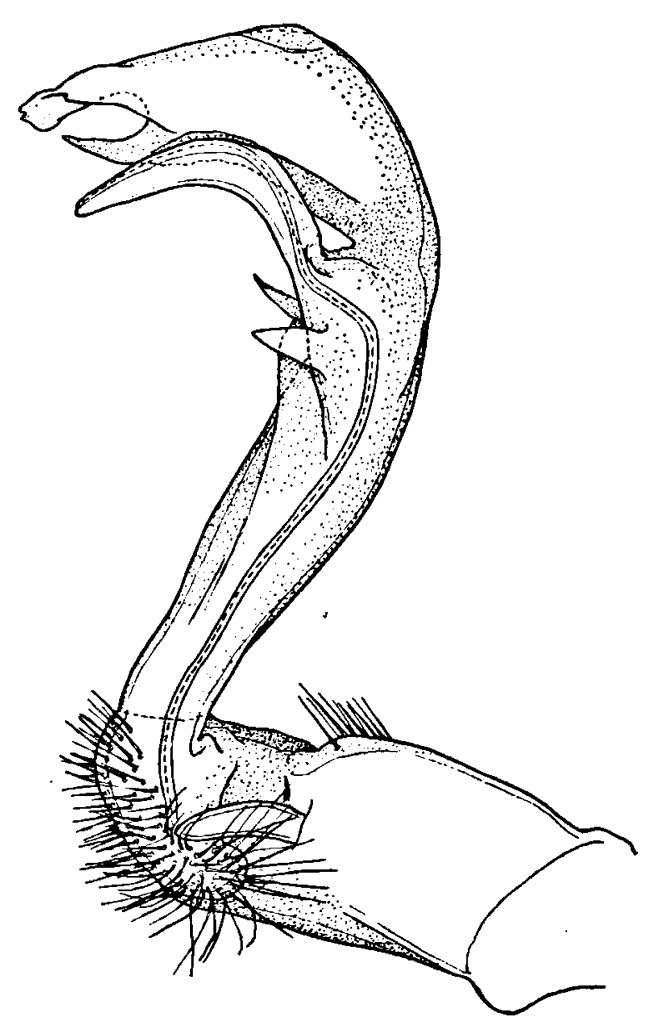

Fig. 31. Sundanina trifasciata (Silvestri, 1895), of lectotype, right gonopod, medial aspect. (only the anterior parts of the body are preserved). On this account they may even belong to a different species.

Re marks. - This species is very well characterized by its colour pattern and gonopods, as well as numerous smaller details. The gonopods are very characteristic indeed by the small size of the two femoral processes and the structure of the, somewhat hood-shaped tibiotarsus. It is hard to indicate any particular relationship with other species of Sundanina and as far as gonopod similarity may be indicative perhaps $S$. simalurensis Jeekel, 1957, may come nearest to $S$. trifasciata. $S$. simalurensis has a relatively voluminous tibiotarsus too, which is also rather abruptly bent caudad at its base. It differs, however, in the irregular shape of the femoral processes, and in many other details as well.

\section{Sundanina niasensis (Silvestri, 1895)}

Strongylosoma niasense Silvestri, 1895: 741.

Sundanina niasensis; Jeekel, 1957: 147, figs. 1-6.

M a te ri a 1. - Nias: Lelemboli, 1886, E. Modigliani, $\hat{\delta}$ lectotype, $2 \delta \hat{\delta}$ paratypes, a fragment of a $\hat{\delta}$ paratype, 1 paratype; Gunung Sitoli, 1886, E. Modigliani, $1 \hat{f}$ paratype, $1 \uparrow$ paratype, a fragment of a $\hat{\delta}$ paratype; Hili Zabobo, VIII.1886, E. Modigliani, 1 of paratype; Bawolovalani, V.1886, E. Modigliani, 2 of $\delta$ paratypes.

Remarks. - A description of this species, based on identified material from Nias, Gunung Sitoli and Lolowua, in the Amsterdam and Leiden museums, was published previously (Jeekel, 1957). The examination of the type material in the Genoa museum has confirmed the identification and has shown a perfect agreement with the published description and drawings, in particular with regard to the structure of the gonopods.

The width of the specimens of the type series varies between 2.5 and $3.1 \mathrm{~mm}$ for the males and 3.7 and $3.8 \mathrm{~mm}$ for the females. The material from Hili Zabobo and Bawolovalani (o 2.5-2.8 $\mathrm{mm}$ ) averages a little less than that from Lelemboli and Gunung Sitoli (o $3.0-3.1 \mathrm{~mm}$, of 3.7 $3.8 \mathrm{~mm}$ ) and the previously recorded material from Gunung Sitoli and Lolowua (o $2.7-3.2 \mathrm{~mm}$, ㅇ $3.4-4.0 \mathrm{~mm}$ ). 
Sundanina carnea (Pocock, 1894)

Strongylosoma carneum Pocock, 1894: 362, pl. XXII figs. 4-4a; Silvestri, 1895 : 742.

Sundanina carnea; Attems, 1935: 114, fig. 1.

Material . - Sumatra, Padang, VIII.1886, E. Modigliani, $9 \hat{\delta} \hat{\delta}$, fragments of $2 \hat{\delta} \hat{\delta}, 4 \$ \$, 1$ juvenile $\hat{\delta}$ with 19 somites.

Re marks. - The identification of the material of this species, which appears to be common around Padang, is herewith confirmed.

Already Pocock (1894) emphasized the variation in colour of his material. The pinkish red colour he mentioned appears to approach the colour of live specimens, but fades when the material is kept in alcohol over a longer period. The colour of the darkest specimens in the series studied is as follows. Head dark coffee brown, darkest in the area of frons and vertex. Labral region yellowish brown. Antennae dark brown, almost blackish, with only the tip of the 7th antennomere whitish. Collum and body somites dark coffee brown, the anterior margin of the collum and the caudal margin of the subsequent somites blackish. Paranota scarcely paler. Venter, sternites and legs yellowish brown. Anal somite including epiproct coffee brown, the paraprocts and the hypoproct yellowish brown. The juvenile specimen is pale brown all over.

The width of the material studied varies between 2.3 and $2.9 \mathrm{~mm}$ for male specimens and 3.0 and $3.6 \mathrm{~mm}$ for female specimens. The juvenile male has a width of $1.9 \mathrm{~mm}$.

For the characters of this species reference is made to the description by Pocock (1894) and the illustration of the gonopods by Attems (1935).

\section{Sundaninella Jeekel, 1968}

Sundaninella Jeekel, 1968: 149.

This genus is very closely related to Sundanina and differs principally in the more erect gonopod telopodite and the more elongate femorite of the gonopods.

Five species have been assigned to it, three of which have been described from Sumatra, one from Indochina, and one from Nias. A redescription of the latter is given here.
Sundaninella elongata (Silvestri, 1895)

Figs. 32-36.

Strongylosoma elongatum Silvestri, 1895: 740.

Materia 1. - Nias: Bawolovalani, V.1886, E. Modigliani, 1 o lectotype, 1 \& paratype; Nias: Hili Zabobo, VIII.1886, E. Modigliani, 1 \% paratype.

Description. - Colour: head castaneous, paler yellowish in the labral region. Antennae light castaneous, the distal part of the antennomeres a little darker than the proximal part, but no distinct annulation. Antennal tip whitish. Body somites including paranota of same colour as the head, the ventral side a little paler, yellowish castaneous. Legs brownish yellow, the distal end of the femur, the entire postfemur and tibia, and the base of the tarsus castaneous.

Width: $\delta: 1.2 \mathrm{~mm}, q: 1.6-1.7 \mathrm{~mm}$.

Head and antennae: labrum widely but rather weakly emarginate, tridentate. Clypeus moderately convex, scarcely impressed towards the labrum. Lateral border faintly rounded, widely emarginate near the labrum. Headplate smooth, polished, moderately pubescent up to above the antennal sockets, vertex with a single pair of hairs. Antennal sockets separated by just a little more than the diameter of a socket or by 5/12th of the length of the 2nd antennomere. Postantennal groove rather deep, the swelling in front weakly prominent. Vertex rather convex, not demarcated from frons, its sulcus not reaching the upper level of the sockets. Antennae very long, rather stout, slightly clavate. Pubescence increasing from moderate in the proximal antennomeres to dense in the distal ones. Relative length of antennomeres: 2nd $<3$ rd $>4$ th $=2$ nd $>$ 5th $>6$ th; the 6th equal to $11 / 13$ th of the length of the 2 nd.

Collum: much narrower than the head, almost semicircular in dorsal outline (fig. 32). Anterior border widely rounded in the middle, becoming gradually a little more strongly convex towards the lateral sides, and then again a little less convex near the lateral margin. Posterior border widely and weakly emarginate in the middle, slightly convex more laterally, and straight near the lateral sides. Lateral border rather widely rounded. Surface smooth, polished, with a few hairs; weakly convex in the middle, distinctly more so laterally. 
Marginal rim of lateral border thin and narrow, the premarginal furrow gradually disappearing in anterior direction.

Body somites: strongly constricted by a broad waist, which is coarsely longitudinally ribbed dorsally downwards to halfway the sides. Prosomites a little dull owing to a fine cellular structure. Metatergites smooth, polished, hairless except in a few anterior tergites where some dispersed hairs are present. Transverse furrow of metatergites distinct, but not sharply impressed, disappearing laterally at a distance from the dorsal furrow of the paranota equal to about two times the dorsoventral diameter of a poriferous paranotum. Transverse furrow present on 5th to 18th somites. Sides smooth, not granular in anterior somites. Pleural keels present only in the 2nd and 3rd somites: in 2nd somite caudally produced in a projecting, finely acuminate, acutely angular process, in 3rd somite represented by a weakly defined ridgelike swelling.

Paranota (figs. 32-33): 2nd somite only slightly

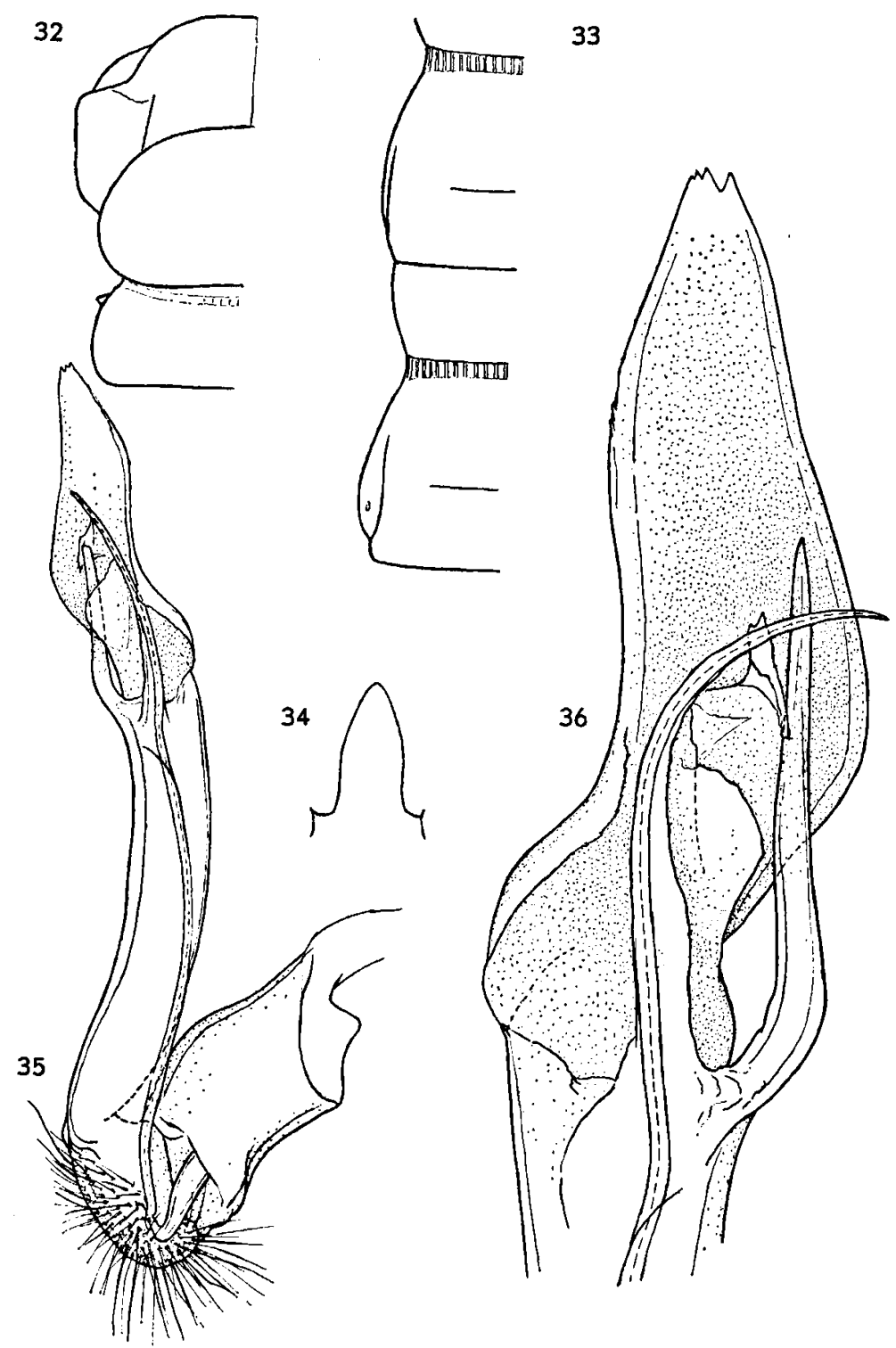

Figs. 32-36. Sundaninella elongata (Silvestri, 1895), \& lectotype: 32, left side of head, collum and 2nd somite, dorsal aspect; 33 , left side of 11 th and 12th somites, dorsal aspect; 34, sternal process of 5th somite, subcaudal aspect; 35 , right gonopod, medial aspect; 36 , apical portion of telopodite of left gonopod, medial aspect. 
narrower than the collum, and as wide as the $3 \mathrm{rd}$ and 4th somites. Paranota of 2nd somite represented by narrow crests, not visible from above except for a small lateroanterior toothlike projection. The lateral border straight, the end not caudally produced. Paranota of 3rd and 4th somites dorsoventrally narrow, only weakly prominent. The dorsal demarcation consists of an anteriorly and posteriorly somewhat upturned furrow. Paranota of 5th and subsequent somites represented by weak prominences, slightly more conspicuous in poriferous somites than in poreless ones. Dorsal demarcation formed by an anteriorly abbreviated furrow which ends well in front of the caudal margin of the somite. Ventral demarcation weakly indicated at posterior side. Pores situated near caudal end in a weak oval impression.

Sternites and legs: sternites of middle somites almost one and a half times longer than broad. Cross impressions well developed, with the transverse impression a little deeper than the longitudinal one. Pubescence rather sparse. Sternite of 5th somite with a deep transverse impression, its caudal half not modified. Its anterior half with a very long process (fig. 34) directed almost straight ventrad and not projecting cephalad of the sternite. A small anterior brush of setae is situated distinctly proximad of apex. Sternite of 6th somite with a broad longitudinal excavation, the transverse furrow weak. Surface of sternite raised slightly above the ventral level of the metasomal ring. Sternite of 7th somite with a weakly developed protuberance on each side laterocephalad of gonopod aperture. Sternite of 8 th somite without modifications. Legs very long and rather slender, the prefemur of all podomeres thickest, but not conspicuously incrassate. Ultimate pairs of legs not elongate. Relative length of podomeres: $3 \mathrm{rd}>$ 6th $>5$ th $>4$ th $=2$ nd; the 6 th podomere equal to $11 / 13$ th of the length of the $3 \mathrm{rd}$. Pubescence of legs rather sparse to moderately dense. Tibial and tarsal brushes present on the legs of first and second pairs, thinned out on legs of 5th somite and probably absent from the legs of 6th somite onwards (part of the legs of single specimen broken off and lost).

Anal somite: epiproct rather short, with sides concave and rather strongly converging. Ventral side a little concave, the dorsal surface with a slight transverse depression halfway. Apex rather broadly truncate, with the paramedian cones very weakly prominent. Preapical lateral granules moderately prominent. Paraprocts with low and moderately wide marginal rims, the setae on low tubercles; surface smooth or slightly rugulose. Hypoproct trapezoidal, the posterior margin slightly convex; setiferous tubercles small, not projecting.

Gonopods (figs. 35-36): coxa and prefemur short. Femorite relatively stout, longish, weakly curved caudad; postfemoral region not demarcated. Spermal channel running along the medial side towards the base of the solenomerite which arises from the medial side of the distal end of the femorite. Caudad of base of solenomerite there is an elongate, slender spine pointing distad. Tibiotarsus consisting of an elongate main lamella, the lamina lateralis. It bears on its medial concavity two irregularly shaped secundary lamellae, possibly the remains of the lamina medialis.

Female: in the paratype from Hili Zabobo the legs are yellowish throughout. Head relatively a little narrower in relation to width of collum. Antennal sockets separated by about two fifths or almost half the length of the 2nd antennomere. Antennae relatively slightly shorter than in the male. Sternites one and one third times longer than broad. Legs relatively a little shorter than in the male.

Remarks. - This species is easily distinguished from the other species of its genus by its relatively stout gonopod femorite, which is also shorter than in the other species. The structure of the tibiotarsus of the gonopods is also diagnostic, as well as many details of the external morphology.

\section{Sundaninella spec.}

Strongylosoma flavicoxis; Silvestri, 1895: 742. Not: Strongylosoma flavicoxis Pocock, 1894: 366.

Materia I. - Sumatra, Siboga [= Sibolga], April 1886, E. Modigliani, 1 ô.

$\mathrm{R}$ e m a r ks . - A male with mutilated gonopods was referred by Silvestri (op. cit.) to the species originally described by Pocock from Paningahan, 
Sumatra. The specimen probably belongs to an undescribed species but could not be described on account of the poor condition of the specimen.

\section{Batakina nov. gen.}

Generic diagnosis. - Rather smallsized Sundaninini with 20 somites and a normal pore formula. Head without particulars; antennae long.

Somites strongly constricted; the stricture broad, coarsely longitudinally ribbed. Metatergites smooth, hairless. Transverse furrow weakly indicated or absent. Pleural keels absent from the 5th somite onwards.

Paranota weakly developed to vestigial.

Sternites of middle somites longer than wide, with well-developed cross impressions. Sternite of 5 th somite of male with a well-developed sternal process between the anterior coxae. Legs long, without distinct tibial and tarsal scopulae in the male, and without particular modifications.

Gonopods with coxa of moderate size. Prefemur subovoid. Femorite of medium length, straight, scarcely widening distally. No demarcation between femoral and postfemoral sections. Spermal channel running straight along the medioanterior side of the femorite towards the base of the solenomerite, which arises at the medioanterior side of the femoral apex. Tibiotarsus relatively large. Lamina medialis strongly reduced, lamina lateralis well developed. Apex of tibiotarsus curving mediad, and slightly caudad. Apex bilobate. From the lamina lateralis arises a laminate process projecting distad of apex of tibiotarsus, and curving mediad. Solenomerite relatively short, applied to the lamina lateralis of the tibiotarsus, and scarcely sheathed by the lamina medialis.

Ty pe-s pecies . - Strongylosoma dentatum Silvestri, 1895.

Remarks. - This genus, which is monotypical, comes nearest to Opisthodolichopus Verhoeff, 1941, but is readily distinguished by the much shorter and stouter femorite of the gonopods. Like Opisthodolichopus it can be separated at once from the other Sumatran Sundaninini by the absence of femoral processes in the gonopods.

\section{Batakina dentata (Silvestri, 1895)}

Figs. 37-42.

Strongylosoma dentatum Silvestri, 1895: 740.

M a te ri a 1. - Sumatra: Si Rambè, 1890-1891, E. Modigliani, of holotype.

De s c ription. - Colour: pale orange castaneous, the 7 th antennomere darkened, the antennal tip whitish. Venter, sternites and legs paler, yellowish brown orange.

Width: $1.3 \mathrm{~mm}$.

Head and antennae: labrum rather deeply and rather narrowly emarginate, tridentate. Clypeus rather weakly convex, moderately impressed towards the labrum. Lateral border faintly convex, a little concave near the labrum. Headplate smooth, rather shiny, moderately pubescent up to the upper level of the sockets, a single pair of hairs on vertex. Antennal sockets separated by about the diameter of a socket or by 5/12th of the length of the 2nd antennomere. Postantennal groove moderately impressed, the swelling in front weakly prominent. Vertex moderately convex, its sulcus rather weakly impressed, not reaching the upper level of the antennal sockets. Antennae long, not particularly slender but rather stout and distinctly clavate. Pubescence of antennomeres moderate, becoming dense in the distal ones. Relative length of antennomeres: 2 nd $<3$ rd $>4$ th $=5$ th $>6$ th. The 6 th antennomere 11/13th of the length of the 2nd.

Collum: narrower than the head, subreniform in dorsal outline (figs. 37-38). Anterior border straight in the middle, more laterally widely rounded, and almost straight again towards the lateral sides. Posterior border widely and weakly concave in the middle, widely rounded more laterally. Lateral border evenly, moderately widely rounded. Surface smooth and shiny, with a few hairs, rather weakly convex in the middle, a little more so towards the sides. Marginal rim of lateral sides thin, scarcely demarcated.

Body somites: strongly constricted; the waist very broad, coarsely longitudinally ribbed down to halfway the sides. Prosomites somewhat dull by 
the presence of a fine cellular structure. Metatergites more shiny, hairless, smooth. Transverse furrow generally absent, sometimes faintly indicated by a depression in the middle. Sides smooth, anterior somites not granular. Pleural keels present only on the 2nd and 3rd somites, represented by distinct ridges, demarcated dorsally by a furrow, curving upward caudally in the 3rd somite. No pleural keels in the 4th somite, only a slight swelling.

Paranota (figs. 37-40): very weakly developed. The 2nd somite is as wide as the collum. The paranota are represented by narrow crests, widest anteriorly, with the anterior edge acutely angular and the anterior border faintly convex. Lateral margin almost straight, posterior edge obtusely angular, slightly produced and projecting a little caudad of the margin of the somite. The $3 \mathrm{rd}$ somite is a little narrower than the 2 nd. Paranota represented only by a slight swelling, dorsally demarcated by a furrow. The 4th somite is as wide as the $3 \mathrm{rd}$, its paranota similar to those of the $3 \mathrm{rd}$. The 5th and subsequent poriferous somites are weakly prominent. Pores in a slight excavation. Poreless somites with a narrow, very low and scarcely defined ridge.

Sternites and legs: sternites of middle somites one and two fifths times longer than broad. Cross impressions well developed. Pubescence moderate to sparse. Anterior part of sternite of 5th somite lost, but according to Silvestri (1895) with a rather large process; caudal part not modified. Sternite of 6th somite with a rather deeply impressed longitudinal furrow, caudally scarcely raised above the level of the metasomal ring. Sternite of 7 th somite with a keellike protuberance laterocephalad of gonopod aperture projecting slightly in front of the sternite. Sternite of 8 th somite not modified. Legs long and slender, the ultimate pairs not particularly elongate. Prefemora very slightly thicker than the other podomeres. Relative length of podomeres: $3 \mathrm{rd}>6$ th $>$ 5th $>4$ th $=2$ nd. Pubescence rather sparse to moderate; the tibiae and tarsi in a few anterior legs ventrally densely setiferous, but without distinct scopulae.

Anal somite (fig. 41): epiproct a little concave ventrally, rather thick, with a slight transverse depression half way the dorsal side. Paraprocts with low and moderately wide rims, setae on low tubercles; surface smooth or a little rugulose.

Gonopods (fig. 42): coxa of moderate length, with an anterior setiferous area. Prefemur rather short, its longitudinal axis oblique on the axis of the femorite. Femorite of moderate length, slightly widening distad; no demarcation between the femoral and postfemoral sections. Spermal channel running straight along the medioanterior side of the femorite towards the base of the solenomerite. Tibiotarsus relatively large, curving mediad and slightly caudad, consisting of a solenophore only. Lamina medialis weakly developed; lamina lateralis strongly developed, giving rise to a distal spatulate blade with serrate margin. The proper ending of the solenophore divided into two parts, a basal lobe and a distal slightly serrate lobe. Solenomerite relatively short, rather strongly curved, ending near the basal lobe of the solenophore.

\section{Tribe TECTOPORINI Jeekel, 1968}

This rather small, and perhaps not yet altogether homogeneous tribe, is represented in the Sunda area by Tectoporus Carl, 1902, known from Sumatra, Java, and southern Celebes, and the probably vicariant, but nevertheless quite distinct genus Eupbyodesmus Attems, 1931, in Borneo. On the Lesser Sunda islands Sumbawa and Flores occurs the genus Paternostrana Jeekel, 1963, which seems rather closely related to Tectoporus. In Indochina the monotypical genus Leiozonius Jeekel, 1963, may belong to the Tectoporini too. The status of the genus Helicorthomorpha Attems, 1914, which occurs from China down to Burma, Indochina, Celebes and New Guinea, within the tribe is more or less arbitrary. No Tectoporini have been recorded from the Malay Peninsula.

\section{Tectoporus Carl, 1902}

Tectoporus Carl, 1902: 567; Jeekel, 1951: 283; Jeekel, 1968 $38,46$.

This well-defined genus was treated in my first paper on the Paradoxosomatidae in 1951, where 

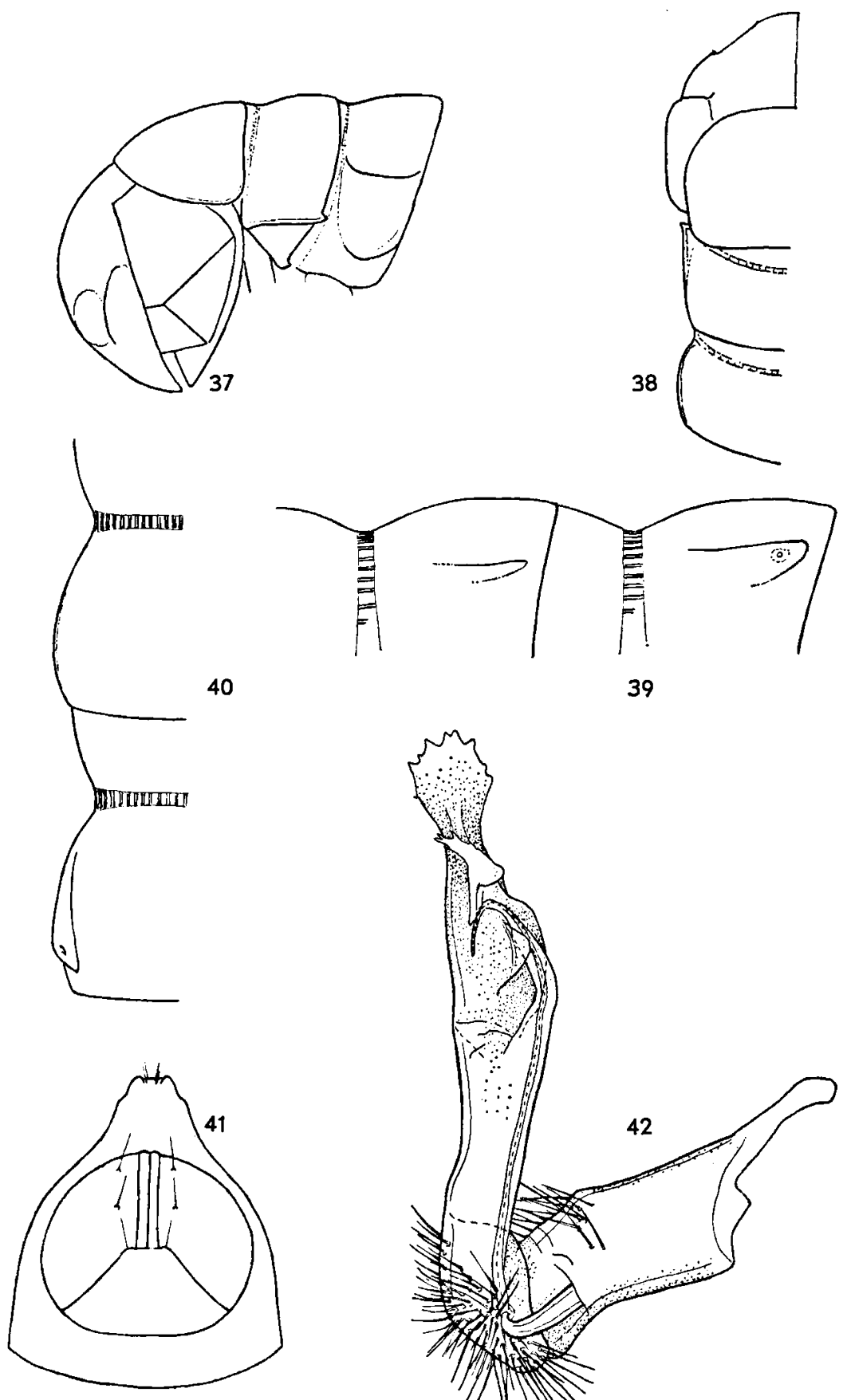

39

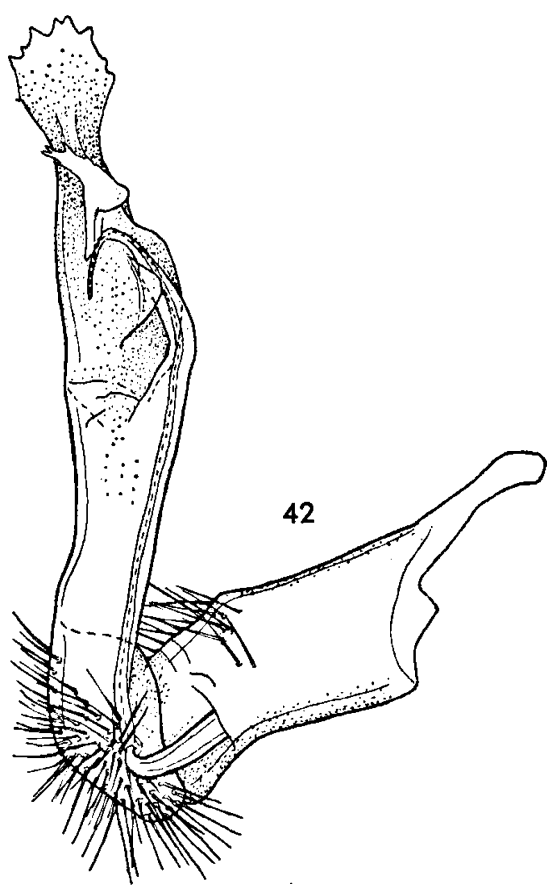

Figs. 37-42. Batakina dentata (Silvestri, 1895), $\hat{\delta}$ holotype: 37, left side of head, collum, 2nd and 3rd somites, lateral aspect; 38 , id., dorsal aspect; 39 , left side of 11 th and 12 th somites, lateral aspect; 40 , id., dorsal aspect; 41 , anal somite, ventral aspect; 42 , right gonopod, medial aspect. 
the generic synonymy was established and a list of the pertaining genera was given. In 1968, some additional species, including the one redescribed below, were referred to Tectoporus, bringing the total number of known species up to 14. By far the majority of these have been described from Java, one from Celebes and two from Sumatra.

\section{Tectoporus hirtellus (Silvestri, 1895)}

Figs. 43-46.

Strongylosoma birtellum Silvestri, 1895: 738.

Materi a 1. - Sumatra: Si Rambè, 1890-1891, E. Modigliani, 1 os (holotype).

D e s cription. - Colour: rather pale reddish castaneous; sternites and legs paler, brownish yellow.

Width: $1.0 \mathrm{~mm}$.

Head and antennae: labrum widely and moderately deeply emarginate, tridentate. Clypeus fairly convex, moderately impressed towards the labrum; its lateral border straight, slightly concave near labrum. Headplate smooth and rather shiny, moderately setiferous up to about the upper level of the antennal sockets; vertex hairless. Antennal sockets separated by about the diameter of a socket or by slightly more than half the length of the 2nd antennomere. Postantennal groove well impressed; the swelling in front rather weakly prominent. Vertex moderately convex; its sulcus weakly impressed, running downward to between the antennal sockets. Antennae of moderate length, rather stout and rather strongly clavate. Pubescence moderate in the proximal antennomeres, becoming dense in the distal ones. Relative length of antennomeres: $2 \mathrm{nd}=3 \mathrm{rd}=4$ th $>$ 5th $=6$ th; the 6th antennomere only a little shorter than the $2 \mathrm{nd}$.

Collum: about as wide as the head, reniform in dorsal outline (fig. 43). Anterior border widely convex, a little more strongly rounded towards the lateral sides. Posterior border widely emarginate in the middle, slightly convex more laterally and finally straight. Lateral border widely rounded, with an obtuse caudal edge. Surface weakly convex in the middle, much more so towards the sides.
Integument shiny, a little uneven, with some dispersed hairs. Marginal rim of lateral border narrow, the demarcating furrow fading away towards the middle of the anterior border.

Body somites: moderately constricted. Waist of moderate width, with a fine but distinct longitudinal striation down to the level of the paranota. Prosomites dulled by a fine cellular structure. Metatergites irregularly uneven, shiny, with rather long hairs irregularly arranged in two or three transverse rows in front of the transverse furrow, and two to three similar rows behind it. Transverse furrow deeply impressed, present from the 5th to the 18th somite. There is a more weakly impressed median furrow, in general distinct only in front of the transverse furrow. Lateral sides of metasomites uneven, subgranular; no pleural keels.

Paranota (figs. 43-44): collum, 2nd and 3rd somites of equal width, the 4th a little wider. Paranota weakly developed. Those of 2 nd somite ridgelike, the lateroanterior edge with a small tooth, the lateral margin slightly undulate. Paranota of 3rd and 4th somites with obtuse posterior edges, a lateral tooth near the anterior edge, the lateral margin widely rounded; dorsoventral width a little larger than in 2nd somite. Paranota of middle somites with the lateroanterior border rather widely rounded, the lateral border straight, the posterior edges very acute, pointed, and in the 15 th and 16th somites spiniform, with the end of the spine turned a little inwards. Lateral border with two indentations. Posterior edges projecting caudad of margin of corresponding metasomite, although very little in the 5 th and 6 th somites. Paranota on a high level, ventrally not or scarcely demarcated by a furrow. Pores not in a distinct concavity, situated lateroventrally and not visible from above.

Sternites and legs: sternites of middle somites about as long as wide. Transverse furrow interrupted in the middle, longitudinal furrow absent, only the coxal sockets somewhat raised, and pointed sternal cones present in post-gonopodial legs, directed caudad. Pubescence of sternites moderate. Sternite of 5th somite damaged, but according to Silvestri the sternal process is short and medially incised. Sternite of 6 th somite not raised above the ventral level of the metasomal ring except at coxal 
bases. Sternite of 7 th somite without particulars, of 8th somite not modified. Legs rather long, moderately slender; the prefemora scarcely incrassate. Pubescence moderately dense, more dense in tarsi, but without brushes; hairs rather long. Relative length of podomeres: 3 rd $>6$ th $>5$ th $>$ 4 th $=2$ nd; the 6 th podomere seven eighths of the length of the $3 \mathrm{rd}$.

Anal somite: epiproct very short, with sides converging almost in a right angle, the end rather narrowly truncate, rounded, without setiferous tubercles or terminal cones. Paraprocts slightly rugulose, marginal rim rather narrow, moderately high. Setae not on tubercles. Hypoproct trapezoidal, sides weakly emarginate, posterior border straight. Setiferous tubercles slightly projecting.

Gonopods (figs. 45-46): coxa, prefemur and femur as typical of the genus. Tibiotarsus consisting of a solenophore without additional processes except for the two basal lamellae of the lamina lateralis characteristic of the genus.
R e m a r k s . - This species has the most simple gonopod structure within the genus, and perhaps approaches as such $T$. annex (Chamberlin, 1945) and $T$. brevipilus (Attems, 1930). Unfortunately, the gonopods of these two Javanese species have not yet been adequately illustrated, so that a detailed comparison is impossible. The differences between $T$. hirtellus, $T$. annex and $T$. brevipilus can, however, easily be established by direct comparison of the general outline of the tibiotarsus in each of them.

In the key to eight species of Tectoporus (Jeekel, 1951: 284) the species redescribed here may be inserted by changing the first couplet as follows:

1. Tibiotarsus of gonopods totally devoid of lamellar expansions except for basal lamellae of the lamina lateralis . . . . . . T. birtellus (Silvestri, 1895)

- Tibiotarsus of gonopods besides the two lamellae of the lamina lateralis either with a large lamellar expansion or with a strong spiniform process at the posterior side near its base

1a. Tibiotarsus with a large lamellar expansion at the posterior side near its base.

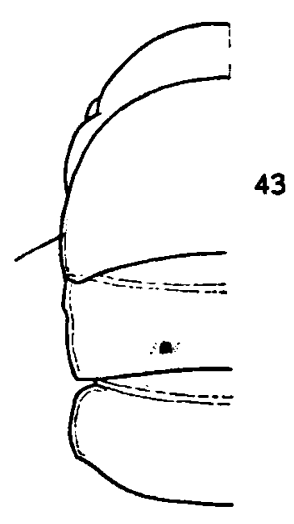

43

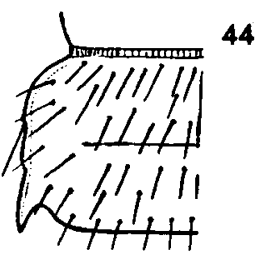

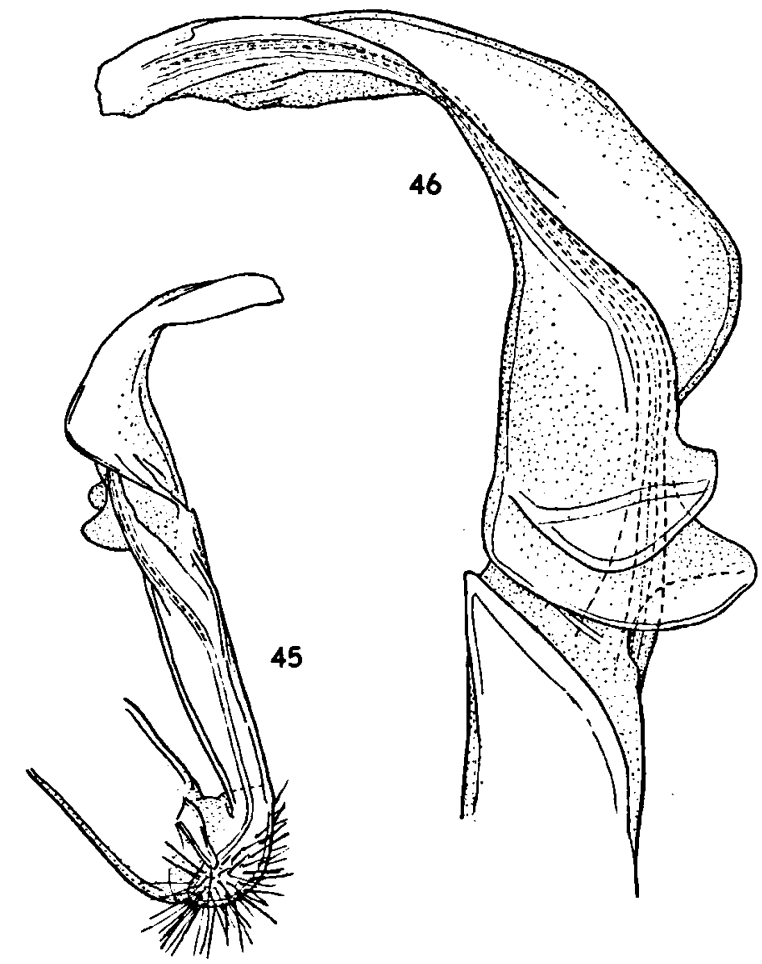

Figs. 43-46. Tectoporus birtellus (Silvestri, 1895), ô holotype: 43, left side of head, collum, 2nd and 3rd somites, dorsal aspect; 44 , left side of 11 th somite, dorsal aspect; 45 , left gonopod, medial aspect; 46 , tibiotarsus of same, lateral aspect. 
- Tibiotarsus with a large spiniform process at the posterior side near its base, pointing in a distal direction. . 4

Tectoporus hispidus Jeekel, 1951

Tectoporus bispidus Jeekel, 1951: 268, figs. 1-4.

M a te ri a 1. - Sumatra: Mt. Singalang, Bella Vista, 25. VII.1878, O. Beccari, $1 \hat{\delta}$.

Remarks. - A male topotype, measuring $1.6 \mathrm{~mm}$ in width, was found in the Genoa museum among unidentified material. It agrees with the description given in 1951.

\section{REFERENCES}

Attems, C., 1914. Die indo-australischen Myriopoden. Arch. Naturgesch., 80A (4): 1-398, pls. I-VII.

- 1935. Myriopoden von Sumatra. Arch. Hydrobiol., Suppl. 14: 114-142.

CArl, J., 1902. Exotische Polydesmiden. Revue suisse Zool., 10: $563-679$, pls. X-XII.

- 1922. Diplopoden aus Sumatra, Java, Malakka und Ceylon. Gesammelt von Herrn Prof. Dr. v. Buttel-
Reepen in den Jahren 1911-1912. Zool. Jb. (Syst.), 44: 565.578.

Jeekel, C. A. W., 1951. The genus Tectoporus Carl (Diplopoda, Polydesmoidea, Strongylosomidae). Ent. Ber., Amst., 13 (311): 266-271; (312): 281-285.

,- 1957 . On three species of Sundanina Att. (Diplopoda, Polydesmida, Strongylosomidae). Ent. Ber., Amst., 17 (8): 147-156.

, 1963. Paradoxosomatidae from Borneo (Diplopoda, Polydesmida). Tijdschr. Ent., 106 (6) : 205-283.

$\longrightarrow$ 1968. On the classification and geographical distribution of the family Paradoxosomatidae (Diplopoda, Polydesmida): i-vii, 1-162 (Ph. D. thesis, University of Amsterdam).

Paradoxosomatidae from Java and Sumatra (Diplopoda, Polydesmida). Revue suisse Zool.

Pocock, R. I., 1894. Chilopoda, Symphyla and Diplopoda from the Malay Archipelago. In: M. WEBER ed., Zoologische Ergebnisse einer Reise in Niederländisch OstIndien, 3: 307-404, pls. XIX-XXII (E. J. Brill, Leiden).

SAussure, H. DE, 1860. Essai d'une faune de Myriapodes du Mexique, avec la description de quelques espèces des autres parties de l'Amérique. Mém. Soc. Phys. Hist. nat. Genève, 15: 1-133, pls. I-VII.

Silvestr, F., 1895. I Chilopodi ed i Diplopodi di Sumatra e delle isole Nias, Engano e Mentavei. Annali Mus. civ. Stor. nat. Genova, 34: 707-760. 